\begin{tabular}{|l|l|}
$\begin{array}{l}\text { 2. To: (Receiving Organization) } \\
\text { SNF K-Basin Projects }\end{array}$ & $\begin{array}{l}\text { 3. From: Criginating Organization) } \\
\text { SNF K-Basin Projects }\end{array}$ \\
\hline 5. Proj./Prog./Dept./Div.: & 6. Design Authority/ Design Agent/Cog. \\
SNF/Debris Removal A.2 & J.B.: Crystal \\
\hline
\end{tabular}

8. Originator Remarks:

The attached OTR is being submitted for approval
4. Related EDT No.:

140396

7. Purchase Order No.:

$$
\text { N/A }
$$

9. Equip./Component No.: N/A

10. System/Bldg./Facility: 105-KE Basin

11. Receiver Remarks: 11A. Design Baseline Document? [] Yes [X] No
12. Major Assm. Dwg. No.:

H-1-81455

13. Permit/Permit Application No.: $\mathrm{N} / \mathrm{A}$

14. Required Response Date: $10 / 31 / 96$

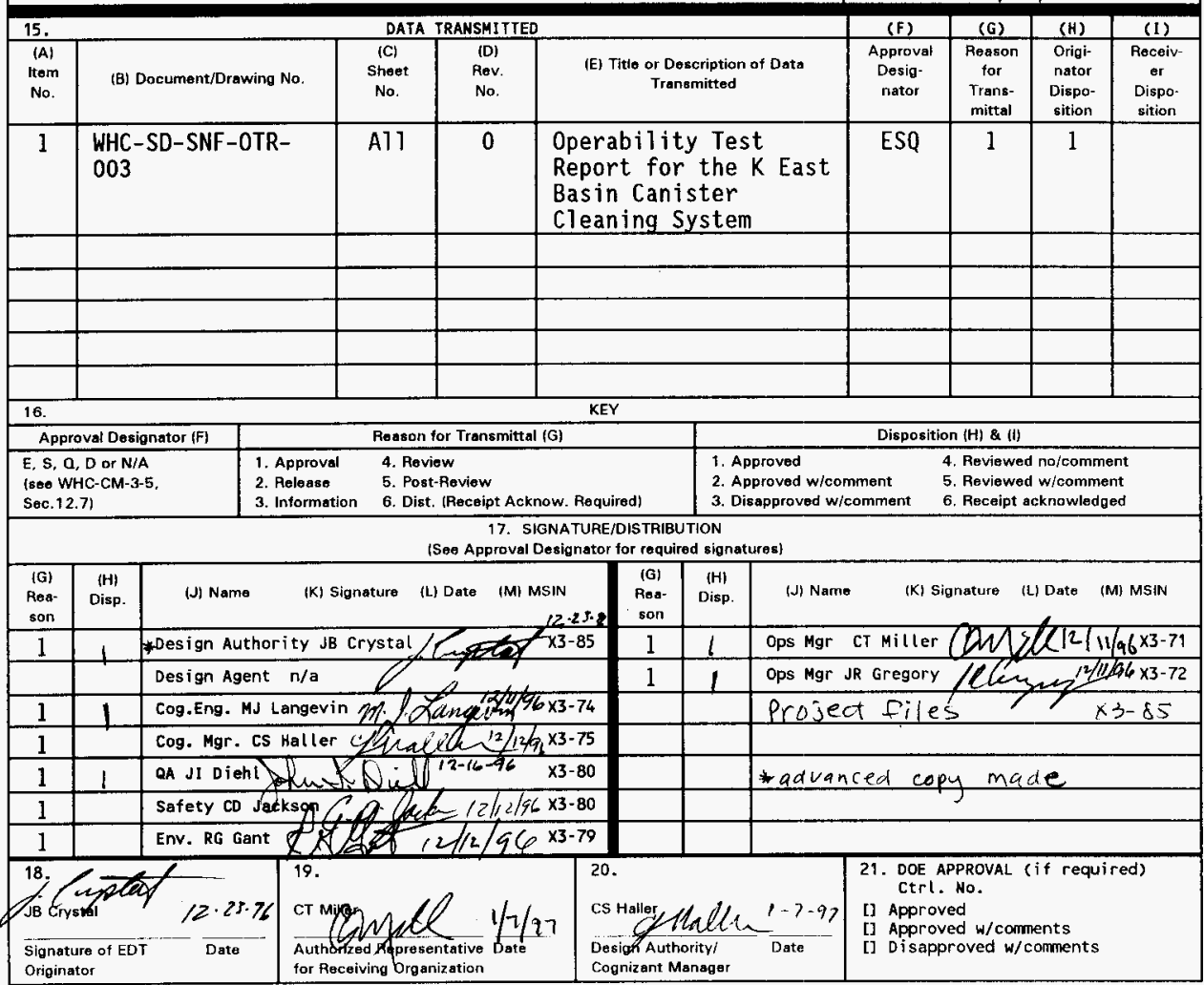

BD-7400-172-2(05/96) GEF097 


\title{
Operability Test Report for the K East Basin Canister Cleaning System
}

Jeremy B. Crystal

Westinghouse Hanford Company, Richland, WA 99352

U.S. Department of Energy Contract DE-ACO6-87Rt+10930 $96 \mathrm{RL}(3200$ (5kB / /9/97)

\author{
EDT/ECN: $619677 \quad$ UC: 510 \\ Org Code: 2T240 Charge Code: LD137 \\ B\&R Code: EW3135040 Total Pages: 5150 (J/CB1/9/97)
}

Key Words: K Basins, Debris Removal, Debris, OTR, Canister

Abstract: This document summarizes test data compilted duringthe operability test procedure for the K East Basin Canister Cleaning System. Test Results show that the canister cleaning system successfully lowered the dose of each canister tested so that each canister could be disposed of as low level waste.

TRADEMARK DISCLAIMER. Reference herein to any specific commercial product, process, or service by trade name, trademark, manufacturer, or otherwise, does not necessarily constitute or imply its endorsement, recommendation, or favoring by the United States Goverment or any agency thereof or its contractors or subcontractors.

Printed in the United States of America. To obtain copies of this document, contact: WHC/BCS Document Control Services, P.O. Box 1970, Mailstop H6-08, Richland WA 99352, Phone (509) 372-2420; Fax (509) 376-4989.
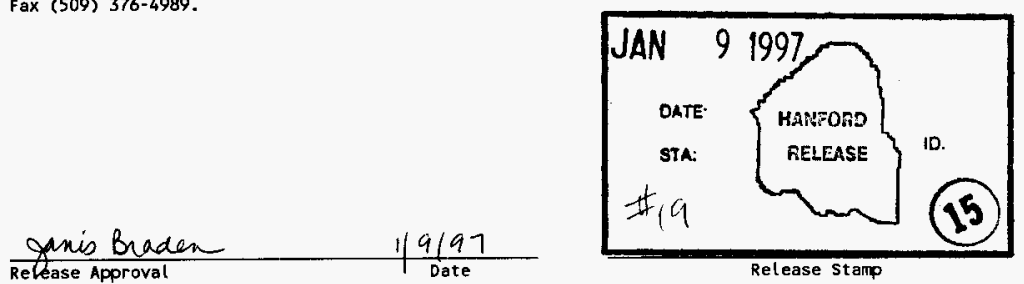

\section{Approved for Public Release}


WHC-SD-SNF-0TR-003 Rev. 0

OPERABILITY TEST REPORT FOR THE

$K$ EAST BASIN CANISTER CLEANING SYSTEM 
WHC-SD-SNF-0TR-003 Rev. 0

\section{ABSTRACT}

The objective of this document is to summarize test data compiled during Operability Test Procedure For the K East Basin Canister Cleaning System. This was performed at $\mathrm{K}$ East Basin in accordance with WHC-SD-SNF-0TP-003. Operability Test Procedure K East Basin Canister Cleaning System. The purpose of the test was to determine if the canister cleaning system would successfulty decontaminate canisters of various types so they could be removed and staged for disposal as low level waste. Test results show that the canister cleaning system successfuily lowered the dose of each canister tested so that the canisters could be disposed of as low-level waste. Furthermore, the test demonstrated that the Canister Cleaning System met the criteria as identified in the Operability Test Procedure K East Basin Canister Cleaning System. WHC-SD-SNF-0TP-003. Although two test descripencies were experienced. both were resolved allowing successful completion of the test. 
TABLE OF CONTENTS

1.0 INTRODUCTION

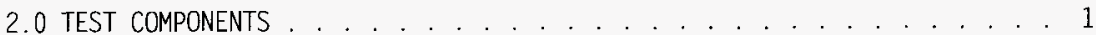

2.1 Equipment . . . . . . . . . . . . . . . . . . . . 1

2.2 Accessories . . . . . . . . . . . . . . . . . . . 2

2.3 Supplies . . . . . . . . . . . . . . . . . 2

3.0 TEST METHOD . . . . . . . . . . . . . . . . . . . 3

3.1 Criteria . . . . . . . . . . . . . . . . . 3

3.2 Test Process . . . . . . . . . . . . . . . . 3

4.0 TEST RESULTS . . . . . . . . . . . . . . . . . . . 5

4.1 Measurements . . . . . . . . . . . . . . . . . . . 5

4.1.1 Underwater Measurements . . . . . . . . . . . . . . . 5

4.1.2 In Air Measurements . . . . . . . . . . . . . . . . . . . 7

4.2 Discrepancies . . . . . . . . . . . . . . . . . . . . 7

4.3 Recommendations . . . . . . . . . . . . . . . . . . 8

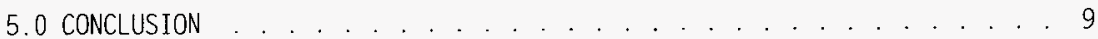

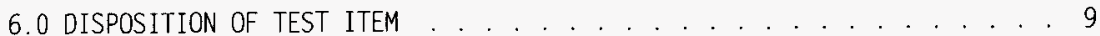

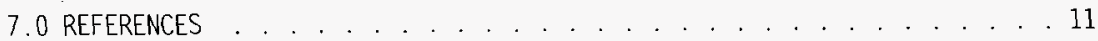

Appendix A: Fuel Storage Canister Drawing . . . . . . . . . . . . A-1

Appendix B: $\log$ Activities . . . . . . . . . . . . . . . B-1

Appendix C: OTP Validation .................... C-1 


\section{WHC-SD-SNF-OTR-003 Rev. 0}

\section{LIST OF TABLES}

TABLE 1- Dose Rate Summaries . . . . . . . . . . . . . . . . 5

TABLE 2 - Dose Survey In Low Background . . . . . . . . . . . . . . . . . 7 
WHC-SD-SNF-0TR-003 Rev. 0

\subsection{INTRODUCTION}

The Operability Test Procedure (OTP) was conducted by $K$ East Basin project engineering, vendor technical representatives, and $K$ Basins operations (4/4/96-4/9/96). See Appendix A for detailed logs and supporting data. The test was witnessed and validated by $K$ Basins quality assurance/quality control $(Q A / Q C)$ personnel and $K$ Basins health physics technicians (HPT).

\subsection{TEST COMPONENTS}

\subsection{Equipment}

Equipment used during the test included the following:

- $\quad$ HEPA filtered Canister Cleaning Fixture Assemb7y. Drawing no. H-1-81455

- Greenhouse Assembly, Roller Conveyor Table, DWG no. H-1-50436 sht. $1 \& 2$

- Accuseal Bag Sealer, model no. 60-734

- Canister Transfer Cart

- R07 Underwater/Waterproof Gamma Radiation Dectector Probe and meter

- Tri Nuclear Vacuum System. model UFV-260; with Accessories and Hoses

- Four Underwater Lights

- Underwater Camera and Monitor

- High Pressure Water Jet System (HPWJS), see below for description

- Eberline R0-3B "Cutiepie" R03 Beta/Gamma radiation detector, max range $5 \mathrm{rad}$

The HPWJS contained the following skid mounted components:

- $\quad$ Butterworth T375H. Model 615 ES Pump, 15,000 PSI a 15 GPM

- Reliance Electric Motor. Model P44G00, $150 \mathrm{HP}, 460 \mathrm{~V}, 170 \mathrm{~A}, 3$ phase, $60 \mathrm{~Hz}$

- Suction Surge Tank, Galvanized 33 gal with stand, 0-160 psig

- Stainless Steel Filter Assembly, 10 micron, 42 GPM

- Discharge Pressure Control Vessel, rated 15000 psi 
WHC-SD-SNF-0TR-003 Rev. 0

- $\quad$ Contactor/Starter. NEMA enclosure, 3R/4 1/2 ATL Starter with stand \& conduit, full voltage, reduced voltage, low amperage draw, slow start

- $\quad$ March Feed Pump, M/N TE-7.5K MD - 2 HP, 460V, 2.6A, 3 phase motor

\subsection{Accessories}

The following accessories were utilized in various combinations to direct and control the water flow from the HPWJS Skid:

- High pressure hose $\frac{1}{2}$ in. ID, 20,000 psi working pressure, 60,000 psi burst pressure, protective outer cover, 9/16 Autoclave Medium Pressure fittings

- $\quad H a n d$ held Wand with $10 \mathrm{ft}$. shielded hose and slimline fitting quick disconnect. 9/16 MP (15.000 psi) Autoclave Medium Pressure fittings. DWG no. H-1-82086

- Three Foot Control Valves 15,000 psi (shut off style) with manifold, piping, fittings mounted on a work stand, DWG no. H-182087

- $\quad$ Skid Stainless Steel Drip Pan

- $\quad$ Feed and drain hoses

- Air manifold and hoses

\subsection{Supplies}

Supplies that were used during the test included:

- Cy7inder of Nitrogen (stored outside of basin only)

- 6 mil flat plastic sleeving, 48 in.dia x $50 \mathrm{ft}$. long (three rolls)

- $\quad$ Shipping containers

- Indelible marker 
WHC-SD-SNF-OTR-003 Rev. 0

\subsection{TEST METHOD}

\subsection{Criteria}

The Operability Test had the following requirements:

- Clean the surface of at least ten(10) canisters to below category three (3). Low Level Waste by reducing the dose rate to less than $100 \mathrm{mrem} / \mathrm{hr}$ at contact out of water and less than $20 \mathrm{mrem} / \mathrm{hr}$ at one meter

- Demonstrate a controlled process for the cleaning/decontamination of canisters underwater with minimal water surface disturbance thereby maintaining air quality within the basin limits

- $\quad$ Perform the step-by-step operating procedures to accomplish OTP demonstrating the effective combinations of fixture nozzles and associated removal equipment

- $\quad$ No Teaks on the HPWJS and hoses during the OTP evaluation

- Validate that routine (prerequisite) facility systems remain operational during the OTP

- Hand held wand and HPWJ skid shall maintain a pressure of 12000 psi (visual at pump) and will not leak

\subsection{Test Process}

Underwater and in-air background dose rate measurements were taken in the vicinity of the canister cleaning system and greenhouse by the HPT and recorded. Canisters were retrieved from various locations in the basin and transferred to the cleaning station canister holder. Fuel storage canisters of type MKO. MKI, and MKII were used for testing. Canister categories are shown in Appendix A. Five canisters of each material type, stainless steel and aluminum were cleaned. At least one of the canisters were open bottom style. Additionally, a finned style canister was cleaned for information purposes only.

Once the canister was positioned for cleaning, a pre-cleaning underwater measurement of the dose rate with both cylinders of the canister were taken using the R07 probe. Each measurement was recorded in the log entries (See Appendix A: Log Entries). The canister cleaning system was then used to clean the inside and outside of the canister. A post-cleaning underwater 
measurement of the dose rate within both cylinders was recorded and compared to pre-cleaning measurements. These measurements are shown in TABLE 1. Dose Rate Summaries.

Cleaning was repeated when necessary until the in-water dose rate readings inside the bottom of both cylinders indicated less than $100 \mathrm{mrem} / \mathrm{hr}$, or the dose could not be decreased (See table 1). If the post cleaning measurement was less than $100 \mathrm{mrem} / \mathrm{hr}$ at contact, the canister was removed from the water into the drip dry greenhouse and surveyed. If canister doses were measured greater than $100 \mathrm{mrem} / \mathrm{hr}$, the canister was returned to the water to be recleaned. If repeated cleaning did not lower the dose count, the canister was to be transferred to a designated storage area for later processing. however this was never necessary during the OTP. Note that MKII stainless steel canisters had to be stood upright on the greenhouse roller conveyor to drain the trunnions.

Once the canister drip dried, it was removed from the hoist and placed on a roller conveyor. Each canister was numbered 1 through 10 with an indelible marker. The right and left cylinders were annotated with "R" and "L" respectively. An HPT obtained two smear samples from each canister: (1) center of the right cylinder, external surface. (2) center of left cylinder, external surface. The locations are shown for clarification in FIGURE 1. Smear Locations.

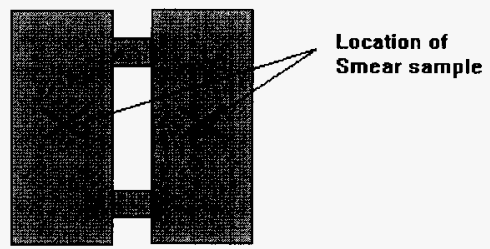

Figure 1 - Smear Locations

The smear samples were bagged and transferred to $183 \mathrm{~K}$ East lab for count analysis and confirmation of radiological characterization as stipulated in document no. WHC-SD-SNF-TI-019. Characterization of Empty Fuel Storage Canisters in 105KE Basin. The canister was then sealed in a plastic bag 
through the bag-sealer and placed into the transfer cart. Finally, the canister was transferred to corridor 7 for final dose measurements. Corridor 7 was used because of the low radiation levels in that area. The canister dose rates are shown in TABLE 2.

\subsection{TEST RESULTS}

\subsection{Measurements}

Tables 1 and 2 shows summary of dose rates measured as described in section 3.2.

\subsubsection{Underwater Measurements}

In Table 1, the "In Water Dose Rate Pre-clean" and "Post-clean" columns are of the format left cylinder/right cylinder. Values in these columns indicate gamma dose rates and were taken using an $\mathrm{RO7}$ underwater probe.

In air dose rate units $\gamma(\mathrm{CW})$ and $\beta(\mathrm{OW})$ are closed window and open window dose $C P$ readings respectively, where closed window indicates that Beta particles are filtered from the total rate, and open window indicates rates that include both Beta and Gamma particles. Data in the In Air Dose Rate column indicate the hottest spot on a canister. Measurements for this column were taken after the canister was heat sealed in a bag and placed in the transfer cart.

TABLE 1- Dose Rate Summaries

\begin{tabular}{|c|c|c|c|c|c|}
\hline \multirow{2}{*}{$\begin{array}{l}\text { Test } \\
\text { no. }\end{array}$} & \multirow{2}{*}{$\begin{array}{c}\text { Canister } \\
\text { Category \& } \\
\text { Type }\end{array}$} & \multicolumn{2}{|c|}{ In Water Dose Rates } & \multirow{2}{*}{$\begin{array}{l}\text { In Air } \\
\text { Dose } \\
\text { Rate } \\
\text { r(cw)mRen/ } \\
\beta(\mathrm{ow}) \mathrm{mRad}\end{array}$} & \multirow{2}{*}{$\begin{array}{l}\text { No. of } \\
\text { Cleanin } \\
\text { gs } \\
\text { Req'd }\end{array}$} \\
\hline & & $\begin{array}{l}\quad \text { Pre- } \\
\text { clean } \\
L(m R) / R(m R)\end{array}$ & $\begin{array}{l}\text { Post- } \\
\text { clean } \\
L(m R) / R(m R)\end{array}$ & & \\
\hline 1 & MKO Al & $100 / 75$ & $23 / 16$ & $11 / 60$ & 1 \\
\hline 2 & MKII SSt & $1000 / 920$ & $27 / 49$ & $7 / 50$ & 1 \\
\hline 3 & MK0 AT & $68 / 105$ & $13 / 18$ & $45 / 255$ & 1 \\
\hline
\end{tabular}


WHC-SD-SNF-OTR-003 Rev. 0

\begin{tabular}{|c|c|c|c|c|c|}
\hline \multirow{2}{*}{$\begin{array}{l}\text { Test } \\
\text { no. }\end{array}$} & \multirow{2}{*}{$\begin{array}{c}\text { Canister } \\
\text { Category \& } \\
\text { Type }\end{array}$} & \multicolumn{2}{|c|}{ In Water Dose Rates } & \multirow{2}{*}{$\begin{array}{l}\text { In Air } \\
\text { Dose } \\
\text { Rate } \\
\text { r(cw)mRem/ } \\
\beta(0 w) \text { mRad }\end{array}$} & \multirow{2}{*}{$\begin{array}{l}\text { No. Of } \\
\text { Cleanin } \\
\text { gs } \\
\text { Req'd }\end{array}$} \\
\hline & & $\begin{array}{l}\text { Pre- } \\
\text { clean } \\
L(\mathbb{m R}) / R(\mathbb{m R})\end{array}$ & $\begin{array}{l}\quad \text { Post- } \\
\text { clean } \\
L(\mathbb{R R}) / R(\mathbb{R})\end{array}$ & & \\
\hline 4 & MKI SSt & $60 / 46$ & $23 / 14$ & $5 / 5$ & 1 \\
\hline 5 & MKO Al & $72 / 62$ & $34 / 22$ & $25 / 100$ & 1 \\
\hline 6 & MKO AT & $121 / 62$ & $50 / 21$ & $120 / 600$ & 1 \\
\hline 7 & MKO Al & $47 / 40$ & $14 / 9$ & $25 / 200$ & 1 \\
\hline 8 & MKII SSt & $53 / 790$ & $17 / 17$ & $6 / 50$ & 3 \\
\hline 9 & MKII SSt & $32 / 34$ & $9 / 25$ & $4.3 / 15$ & 1 \\
\hline 10 & MKII SSt & $93 / 59$ & $31 / 26$ & $9 / 18$ & 1 \\
\hline 11 & $\begin{array}{c}\text { MKO Al } \\
\text { (Fin/Slot) }\end{array}$ & $51 / 48$ & $12 / 23$ & $16 / 90$ & 1 \\
\hline \multicolumn{6}{|c|}{$\begin{array}{l}Y(\mathrm{CW})=\text { Gamma dose, } \text { closed window } \mathrm{CP} \\
\beta(\mathrm{OW})=\text { Beta and Gamma dose rate, open window } \mathrm{CP} \\
\mathrm{Al}=\text { Almunimum } \\
\text { SSt= Stainless Stee }\end{array}$} \\
\hline
\end{tabular}

Note, that except for one canister, canister no. 6, the desired limit for a maximum contact in-air dose (100 mR) was achieved as indicated in the system criteria. The resolution for the high dose on canister 6 was recorded and resolved on test discrepency no. 1. see section 4.2 for details. Canister 8 in water dose rate was also high. (350/33) after one cleaning. This was corrected by recleaning the MKII SST canister two additional times. Once with the fixture, and once using the hand wand. Using the fixture did not improve the dose count: however, cleaning was more effective with the hand wand. The final in-water-dose rate after the addtional cleanings was $17 / 17$. 
WHC-SD-SNF-OTR-003 Rev. 0

\subsubsection{In Air Measurements}

TABLE 2 shows the dose counts from the side of each canister in a low dose area. As was the case in TABLE 1 values $\gamma(\mathrm{cw})$ and $\beta(\mathrm{ow})$ are closed window and open window dose readings respectively.

TABLE 2 - Dose Survey In Low Background

\begin{tabular}{|c|c|c|c|}
\hline $\begin{array}{l}\text { Test } \\
\text { no. }\end{array}$ & $\begin{array}{l}\text { Canister } \\
\text { Category \& } \\
\text { Type }\end{array}$ & $\begin{array}{c}\text { Dose Rate, Left } \\
\text { Cylinder } \\
\text { YmRem(cw)/BmRad(ow) }\end{array}$ & $\begin{array}{c}\text { Dose Rate, Right } \\
\text { Cyl inder } \\
\text { YmRem(CW)/BmRad(ow) }\end{array}$ \\
\hline 1 & MKO AT & $6 / 30$ & $5 / 20$ \\
\hline 2 & MKII SST & $<0.5 / 2$ & $<0.5 / 2$ \\
\hline 3 & MKO AT & $5 / 30$ & $6 / 30$ \\
\hline 4 & MKI SST & $<0.5 / 2$ & $<0.5 / 3$ \\
\hline 5 & 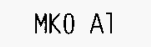 & $6 / 5$ & $5 / 12$ \\
\hline 6 & MKO Al & $7 / 21$ & $10 / 15$ \\
\hline 7 & MKO AT & $2 / 10$ & $1.5 / 8$ \\
\hline 8 & MKII SST & $2 / 2.5$ & $2 / 2.5$ \\
\hline 9 & MKII SST & $1.5 / 2$ & $1 / 1.5$ \\
\hline 10 & MKII SST & $2 / 3$ & $2.5 / 2.6$ \\
\hline 11 & $\begin{array}{c}\text { MK0 A1 } \\
\text { (Fin/Slot) }\end{array}$ & $15 / 27$ & $5 / 14$ \\
\hline
\end{tabular}

From this data, it can be seen that most of the dose count readings shown in TABLE 1 one are due to background radiation. The background dose was measured to be $4 \mathrm{mRem}$. Note, the dose rates in table 2 are on the sides of the cylinders, whereas the in-air dose rates in TABLE 1 were the hottest spot on the canisters, typically the bottoms. 
WHC-SD-SNF-0TR-003 Rev. 0

\subsection{Discrepancies}

There were two test discrepencies during the testing phase. A test descrepancy was defined as a step in the operability test that failed to meet the test criteria. The test criteria is identified in the OTP and summarized in section 3.1 .

The first discrepency occured at 10:30pm. 4/5/96 when canister \#6 had a hot spot on its bottom measuring $120 \mathrm{mR}$ on contact. This was not discovered until after a bag had been sealed around the canister. After consulting with the HPT this was deemed acceptable since the average canister dose was 10-20mR, and the $120 \mathrm{mR}$ only contributed $2 \mathrm{mR}$ at $1 \mathrm{ft}$. to the background dose.

Furthermore, there was no violation of the RWP which allowed $100 \mathrm{mR}$ whole body dose.

The second discrepancy occured at 9:00pm, 4/9/96 when the high pressure water jet pump pressure dropped to 10,000psi. The inner nozzles being used were specified at 12,000psi. The HPWJS continued to decontaminate canisters just as well as the specified 12,000psi. The system achieved the same cleaning effectiveness and successfully decontaminated canisters below the $100 \mathrm{mR} / \mathrm{hr}$ limit: however. the inner cleaning nozzles were replaced to restore the pressure to the proper operating pressure specification.

The test discrepancy log and test discrepancy forms are attached in Appendix B.

\subsection{Recommendations}

To resolve future occurences where a canister dose measures above the acceptable maximum limit. similar canisters should be examined more thoroughly for dose while in the Green House where it is easier to return the canister to the basin for additional cleaning.

The operating pressure should be modified to allow pressure drops on the HPWJ to 10,000 psi or until cleaning effectiveness is lost. If the pressure drops below the specified pressure, changing the nozzles will correct the problem.

It should be also be noted that the heat sealer was not always making a complete, or satisfactory seal around the bag edge. Heating time had to be adjusted at the start up to produce satisfactory seals. The operating 
WHC-SD-SNF-0TR-003 Rev. 0

procedure should be corrected to instruct operations to make several seals to warm up the bag sealer, and to always check the bag edges to insure a proper seal.

Several modifications to the system should be considered for greater efficiency and a safer operability:

- The hoist handle for the hoist inside the greenhouse needs to be cut back so operators do not injure their heads.

- Presentiy the greenhouse pendant interferes with the ability to raise a can. The pendant should be pulled out further to correct this inconvenience.

- The canister transfer cart needs a neoprene pad on the bottom to avoid damaging the canister during transport. A thicker bag (10 mi1) will also aid in avoiding tears.

- A work table, or cart for staging supplies is needed near the cleaning area.

- The roller conveyor needs to be rinsed every shift so that smear sample counts will not be affected by previous canister runs and to control build up of contamination.

\subsection{CONCLUSION}

Although there are adjustments that must be made to the cleaning process, the requirment to clean. seal, and store ten canisters from the basin was met.

All results clearly show that the canister cleaning system will decontaminate canisters in the KE Basin such that the contact dose rate is less than $100 \mathrm{mrem}$. All criteria described in section 3.1 were met and validated as evidenced in WHC-SD-SNF-0TP-003, Operability Test Procedure K East Basin Canister Cleaning System. Copies of the signatures used to validate the OTP have been provided for reference in this report and can be found in Appendix c.

\subsection{DISPOSITION OF TEST ITEM}

Since the Canister Cleaning System Operability Test was successful, a11 
components discussed in the report may remain in the Basin until approximately 5600 canisters have been removed from the water pool. and stored for later staging. It is estimated that this process wi 11 not be finished until February in the year 2000. Until all canisters are cleaned the HPWJ, greenhouse, pumps, etc. should remain in the basin for continual use. 


$$
\text { WHC-SD-SNF-OTR-003 ReV. } 0
$$

\subsection{REFERENCES}

WHC-SD-SNF-0TP-003, Operability Test Procedure K East Basin Canister Cleaning System.

Dwg. H-1-81455, Canister cleaning Fixture Assembly and Fabrication Sections and Details.

Dwg. H-1-50436, Canister Cleaning Drip-Dry Greenhouse.

Dwg. H-1-82086, Hand Held Wand.

Dwg. H-1-82087, Foot Control, Air control, Operation Station.

WHC-SD-SNF-TI-019 Rev.0. Characterization of Empty Fuel Storage Canisters in 105-KE Basin. 


\section{WHC-SD-SNF-OTR-003 Rev. 0}

Appendix A: Fuel Storage Canister Drawing

A-1 


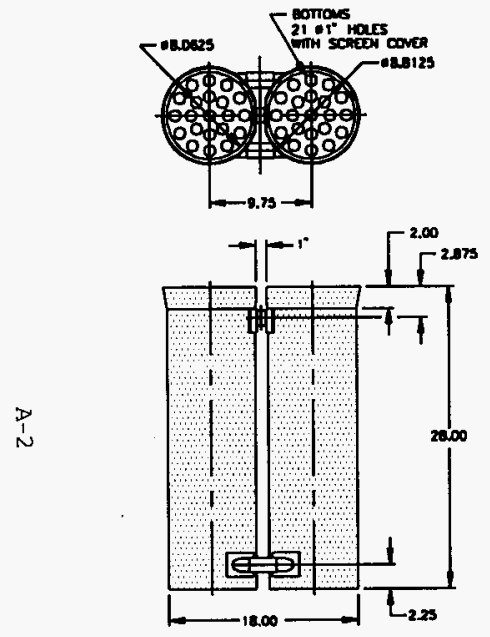

MARK 0 CANISTERS

(H-2-36935)
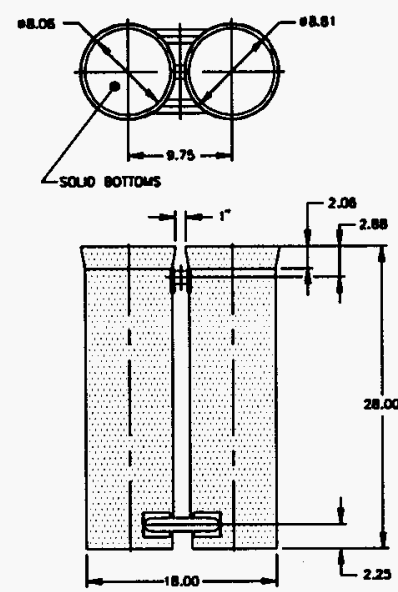

MARK । CANISTERS

(H-2-42793)
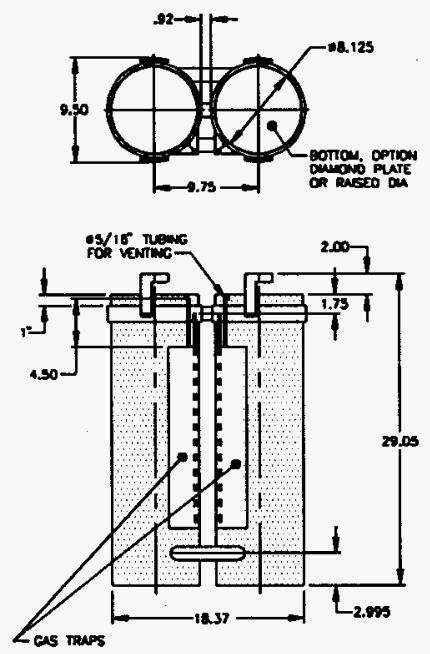

MARK II CANISTERS

(H-2-46215)

105-N REACTOR FUEL STORAGE CANISTERS (FB10009A) 
WHC-SD-SNF-0TR-003 Rev. 0

Appendix B: Log Activities

B-1 


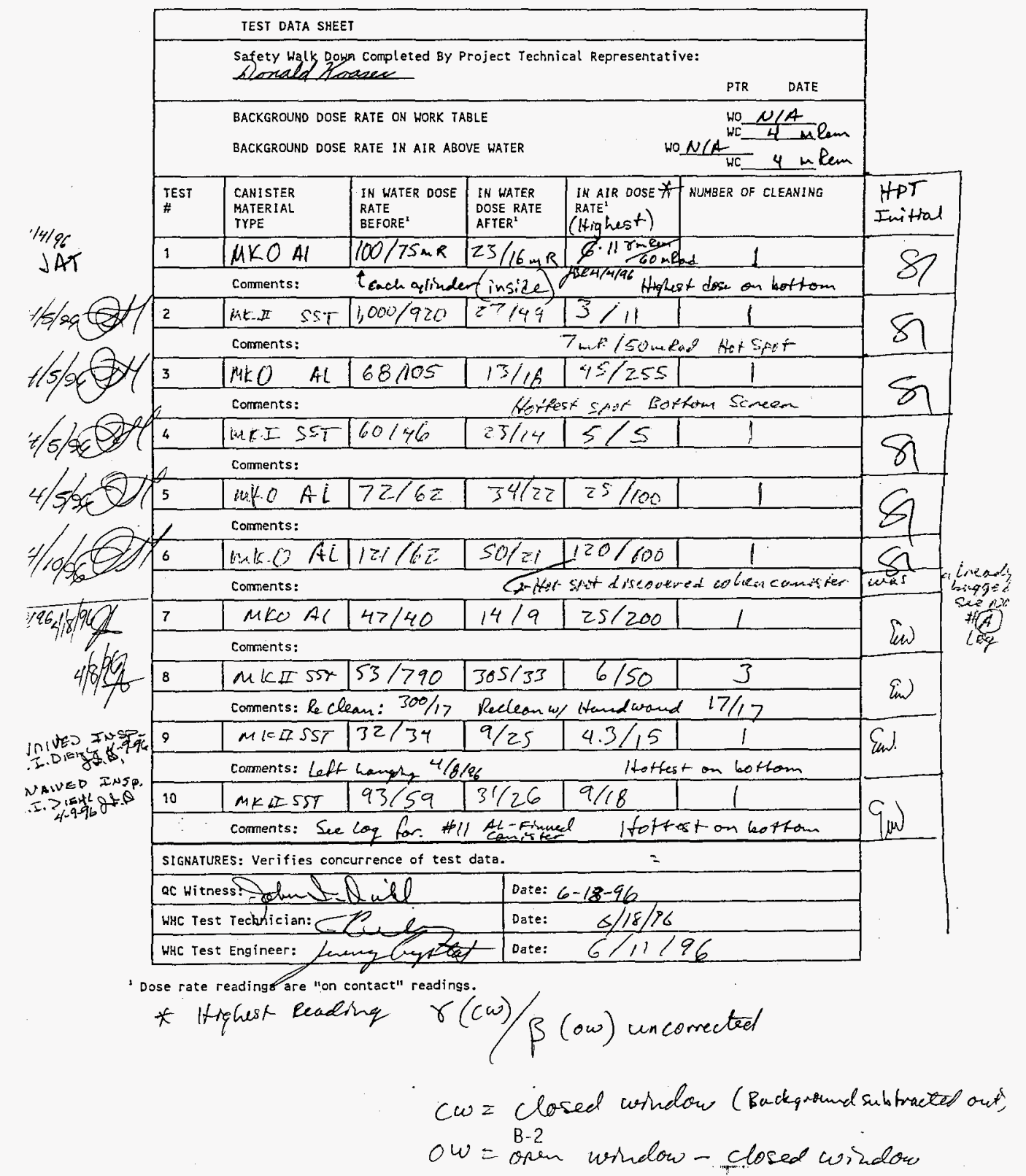




$$
\text { WHC-SD-SNF-0TR-003 revo }
$$

side canister low backgroud in rorrilor.

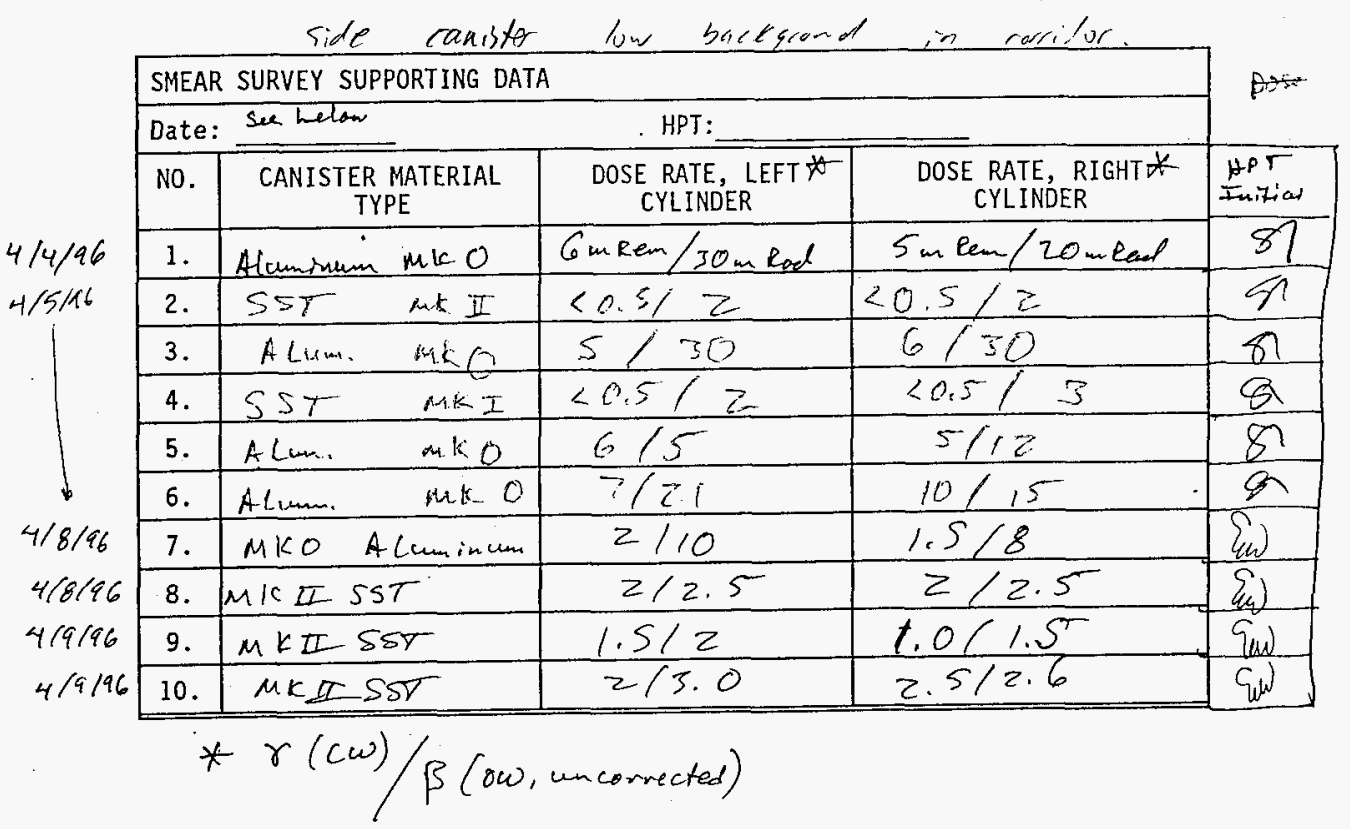

$c \omega=$ closed worndow
$o w=$ opem window - closed wrindow

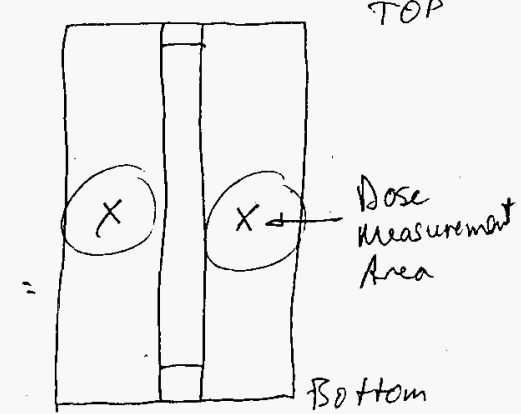

Bottom

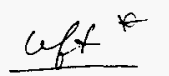

$15 / 27$
$\underline{R z L t}^{*}$

$5 / 14$
11. MKOAC

Finned slotted

B-3 


\section{ACCEPTANCE SHEET}

$\sqrt{V}$ The following items have been demonstrated successfully for acceptance of this OTP:

D. Validate that routine facility systems are operational during the OTP.

DV Clean the surface of ten (10) canisters below Category III, Low Level Waste. Reduce the dose rate to less than $100 \mathrm{mrem} / \mathrm{hr}$ at contact in air and less than $20 \mathrm{mrem} / \mathrm{hr}$ at one meter.

Q Minimal water surface disturbance, maintaining air quality within the basin limits.

Q Maintain a minimum of 12,000 psi at the HPWUS Skid during cleaning.

[0 Verify the step-by-step operations procedures used to accomplish operability testing.

(4) Maintain no leaks on the high pressure water system and hoses during the test evaluation.

Acceptance is endorsed by the following organizations and personnel:

The Operability Test Procedure for the HPWJS Canister Cleaning Fixture and associated tools and equipment has been satisfactorily completed.

\begin{tabular}{|l|l|}
\hline & Sate \\
\hline Test Engineer: & $6 / 11 / 96$ \\
\hline Project Cognizant Engineer: & $6 / 11 / 96$ \\
\hline K Basin Operations Manager: & $6 / 25 / 96$ \\
\hline Plant Engineer: & $6 / 18 / 96$ \\
\hline Radiological controls: & $6 / 18 / 96$ \\
\hline Safety: & $6 / 18 / 96$ \\
\hline OA: & $6 / 18 / 96$ \\
\hline Environmental: & \\
\hline Project Technical Representative: & \\
\hline
\end{tabular}


WHC-SD-SNF-OTR-003 ReNO

Test Discrepancy Log

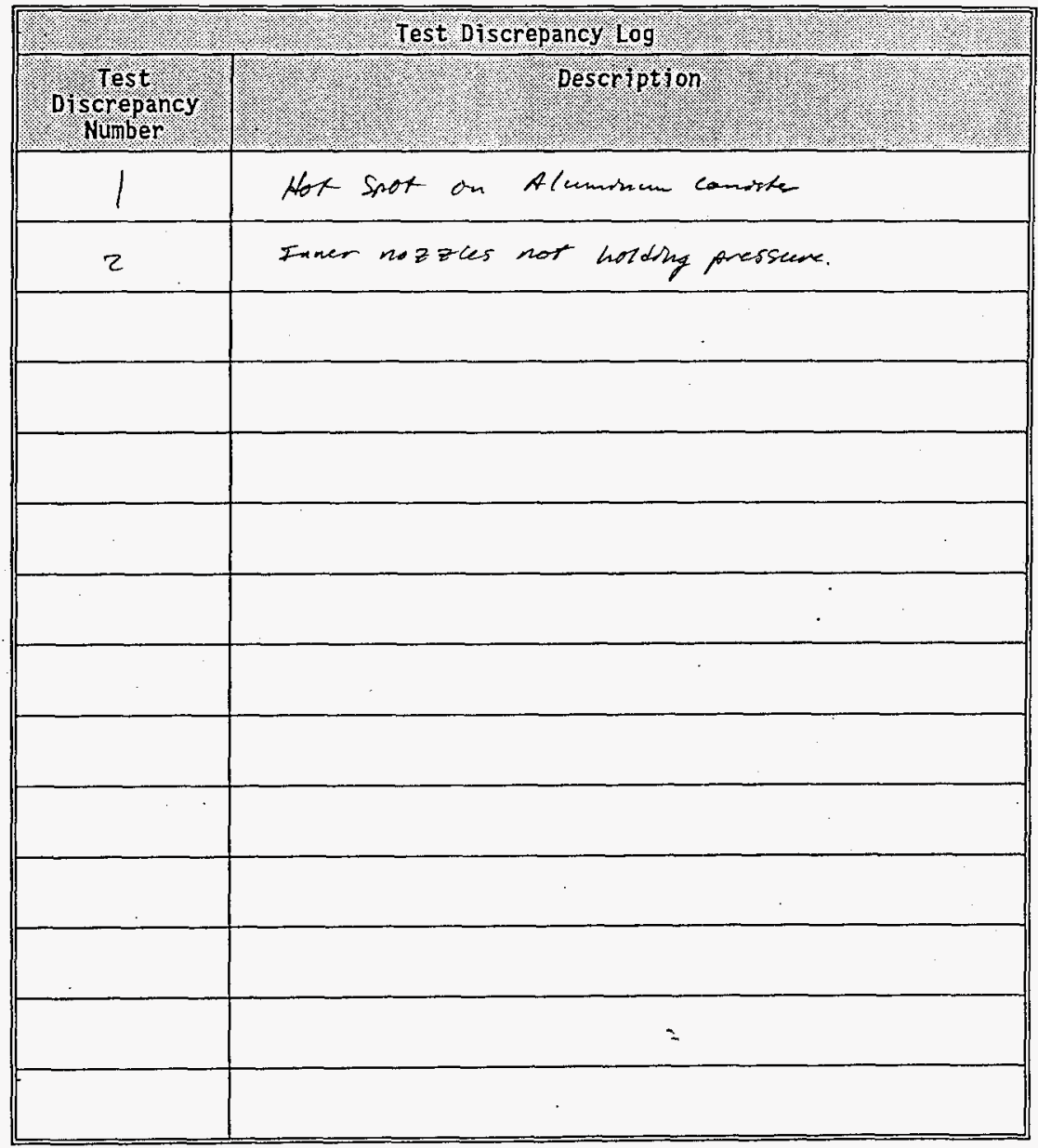




\section{Instructions}

1. Enter time, date and OTP test section(s).

2. Enter discrepancy number obtained from the test discrepancy log.

3. Enter description and disposition/justification of discrepancy.

4. Obtain applicable approval signatures as described below.

5. Implement the disposition.

6. Test Engineer sign and date the "completed" block when disposition has been implemented.

\section{Disposition Approval Signatures}

A. Manager: Only if disposition does not meet original intent of the OTP or if discrepancy form is being used to change the OTP instructions.

B. Test Director: Al] discrepancies not completed within 8 hours.

C. Test Engineer: All discrepancies.

D. Safety: For dispositions that change safety related OTP test instructions.

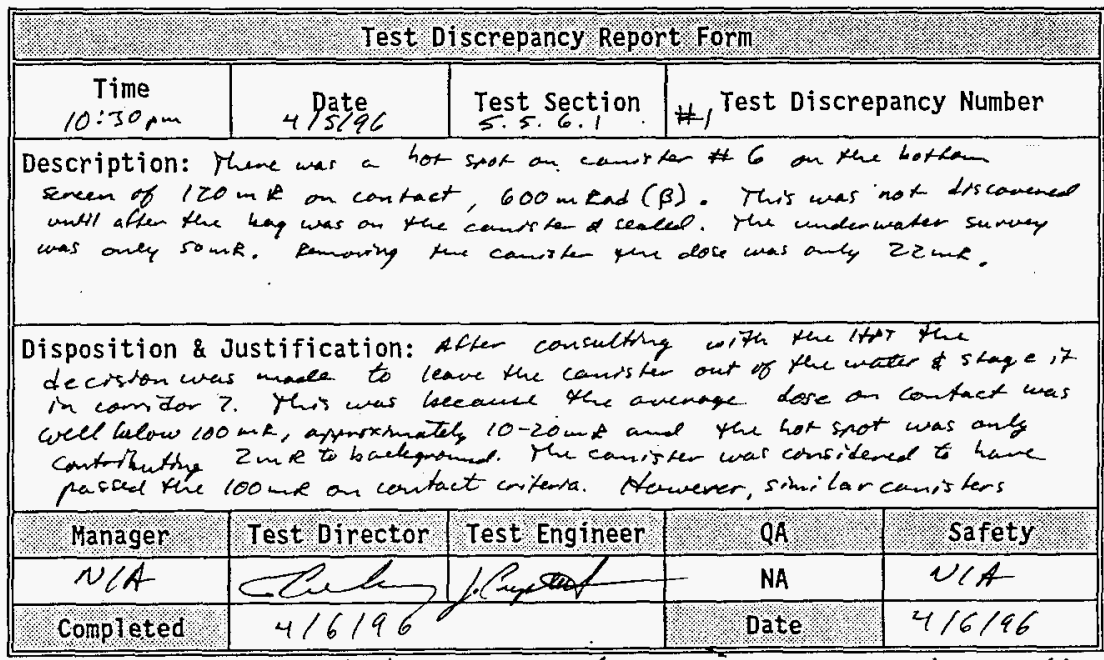

should he cleaned twice and checked more thon thorougly when in the queen hance for doce. The higher dose comiram will be completely arsayed of if it does not meet cal. III CCW criteria it will be put kack in the bash. 


$$
\text { WHC-SD-SNF-OTR-003 new O }
$$

Instructions

1. Enter time, date and OTP test sections).

2. Enter discrepancy number obtained from the test discrepancy $10 \mathrm{~g}$.

3. Enter description and disposition/justification of discrepancy.

4. Obtain applicable approval signatures as described below.

5. Implement the disposition.

6 . Test Engineer sign and date the "completed" block when disposition has been implemented.

Disposition Approval Signatures

A. Manager: Only if disposition does not meet original intent of the OTP or if discrepancy form is being used to change the ore instructions.

B. Test Director: All discrepancies not completed within 8 hours.

C. Test Engineer: All discrepancies.

D. Safety: For dispositions that change safety related OTP test instructions.

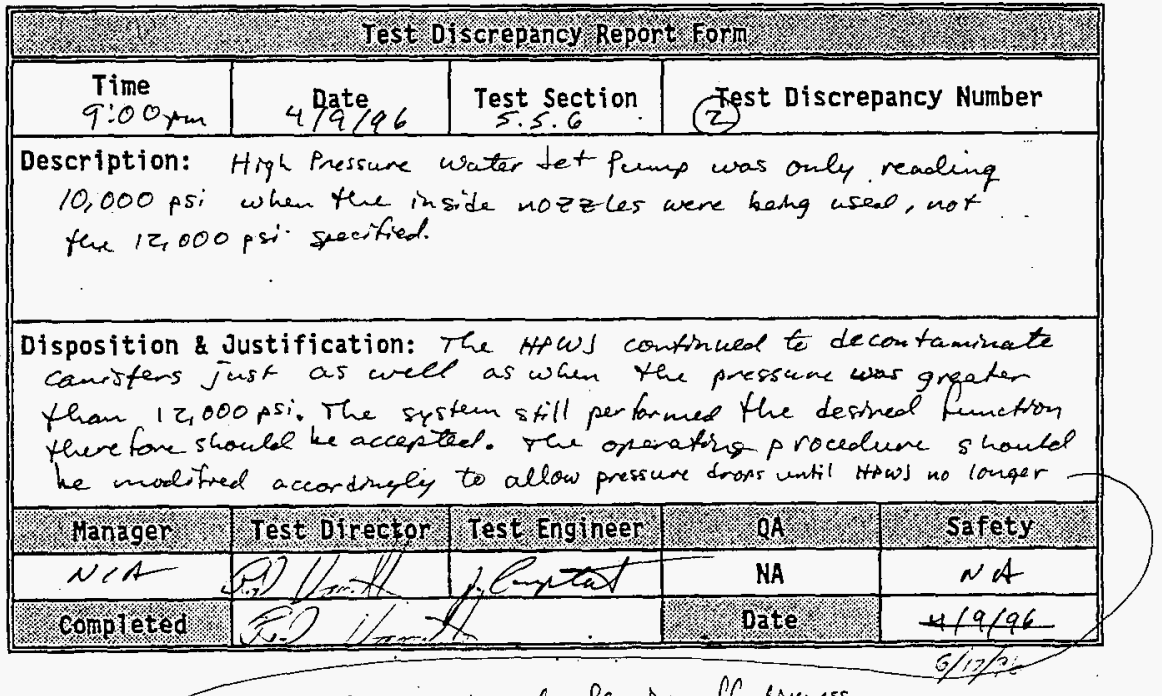

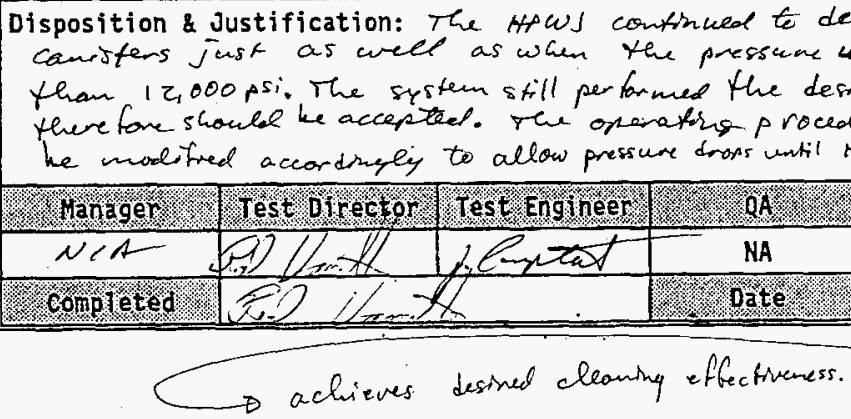

The Hows needs to he rue for addition el time te determine if pressure will continue to drop indio indicating a.

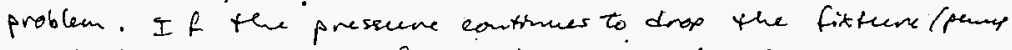
needs to be foxed ceahieve the required pressure $10,000-15,000$ sis without troperige.

Resolution: Ire cleanly nozzles were red aced, pressers was restored to 14,000-15,000, s.: B-7 
$4-10 \cdot 96$

$$
\text { WHC-SO-SNF-OTR-003 re } 0
$$

Pressure gauge

i 1 ix mm outlet

\begin{tabular}{l|l}
\hline start & 22 psi \\
opened lx av 229 & pressure draped to $18 p$ si i climbed back to 22 psi
\end{tabular}

started feedwiter point

$22 p s t$

started High press. pin

$19 p s i$

inside peddle depressed 19 psi \& 10,000 psi an High press a aube

outside peddle depressed 19 psi

Hand wand depressed

$19 p 5 i$

- At this point, we throttled $1 \times M V 209$ ( $1 \times m$ oftetdischarge)

to bring pressure up to $22 p s i$. (from 1qpsi)

inside peddle depressed - after 5 minutes to pressure dropped for about a second to 6,000 psi a then ins ede pressed for buck up to 10,000 psi. (1 $1 \times m$ flow $=105 \mathrm{gpm}$ ) dill of this

Throttled ix outlet up to $25 \mathrm{psi}$. The $x^{\mathrm{m}}$ flow dropped period

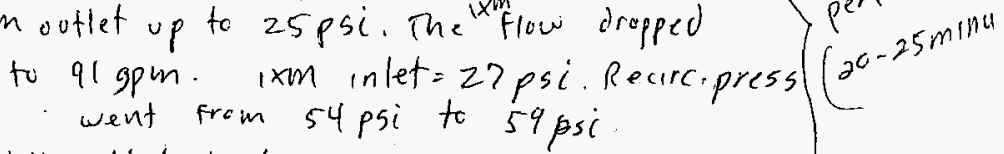

Throttled itu cutlet back to 19psi. Recline $=56 \mathrm{fsi}$ Pressure dropped to 7500 psi for one second \& beck up to 10,000 psi

suet high press. pump off

$1 \times m$ outlet $=22$ s si

xe in let $=26$ psi

How $=103 \mathrm{gpm}$.

Recire. pressure $=58$ ps $i$

Be 
WHC-SD-SNF-OTR-003 revo

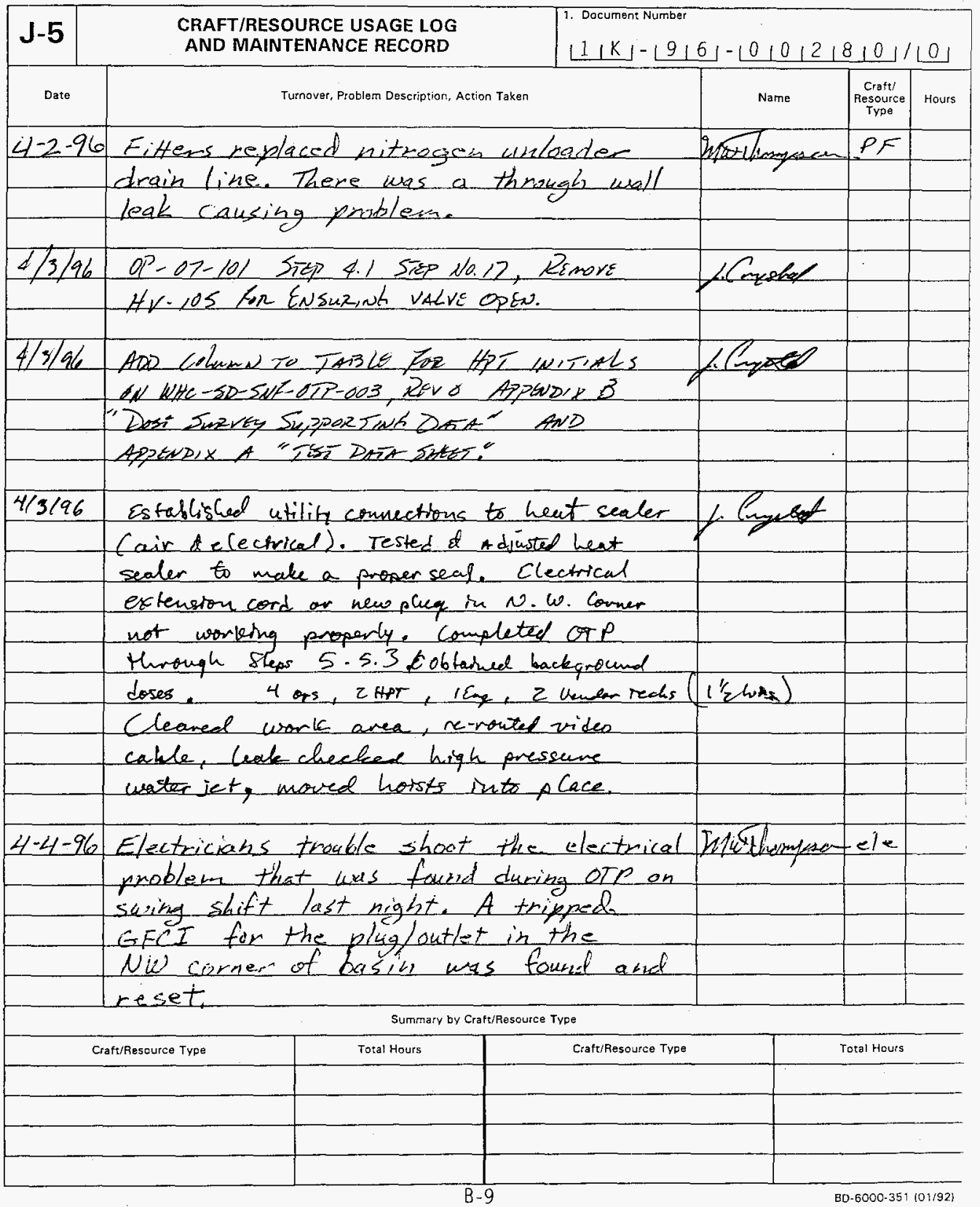


WHC-SD-SNF-OTR-003 reNo

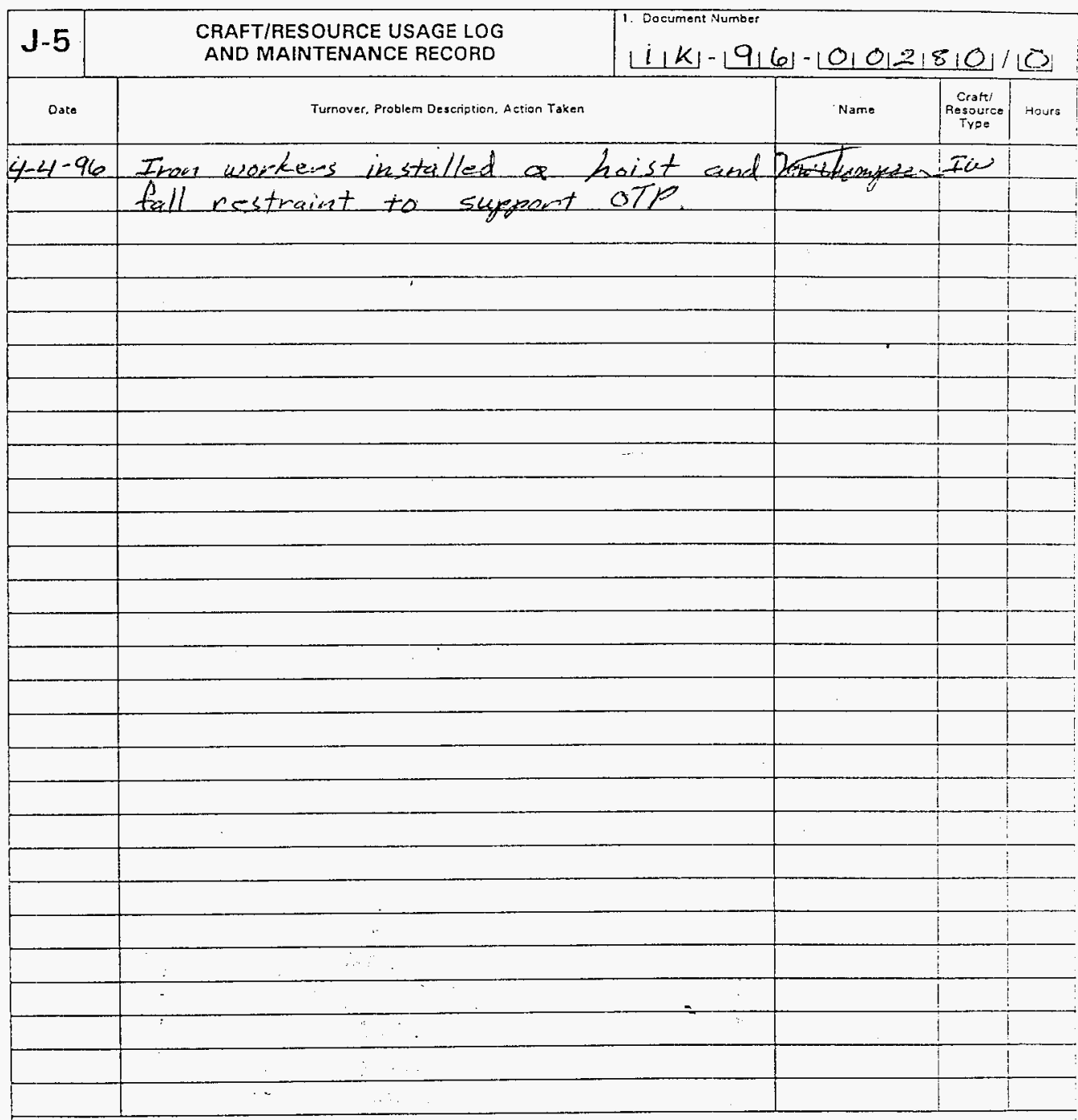

Summary by Cratt/Resource Type

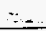




$$
\text { WHC-SD-SNF-OTR-003 rev o }
$$

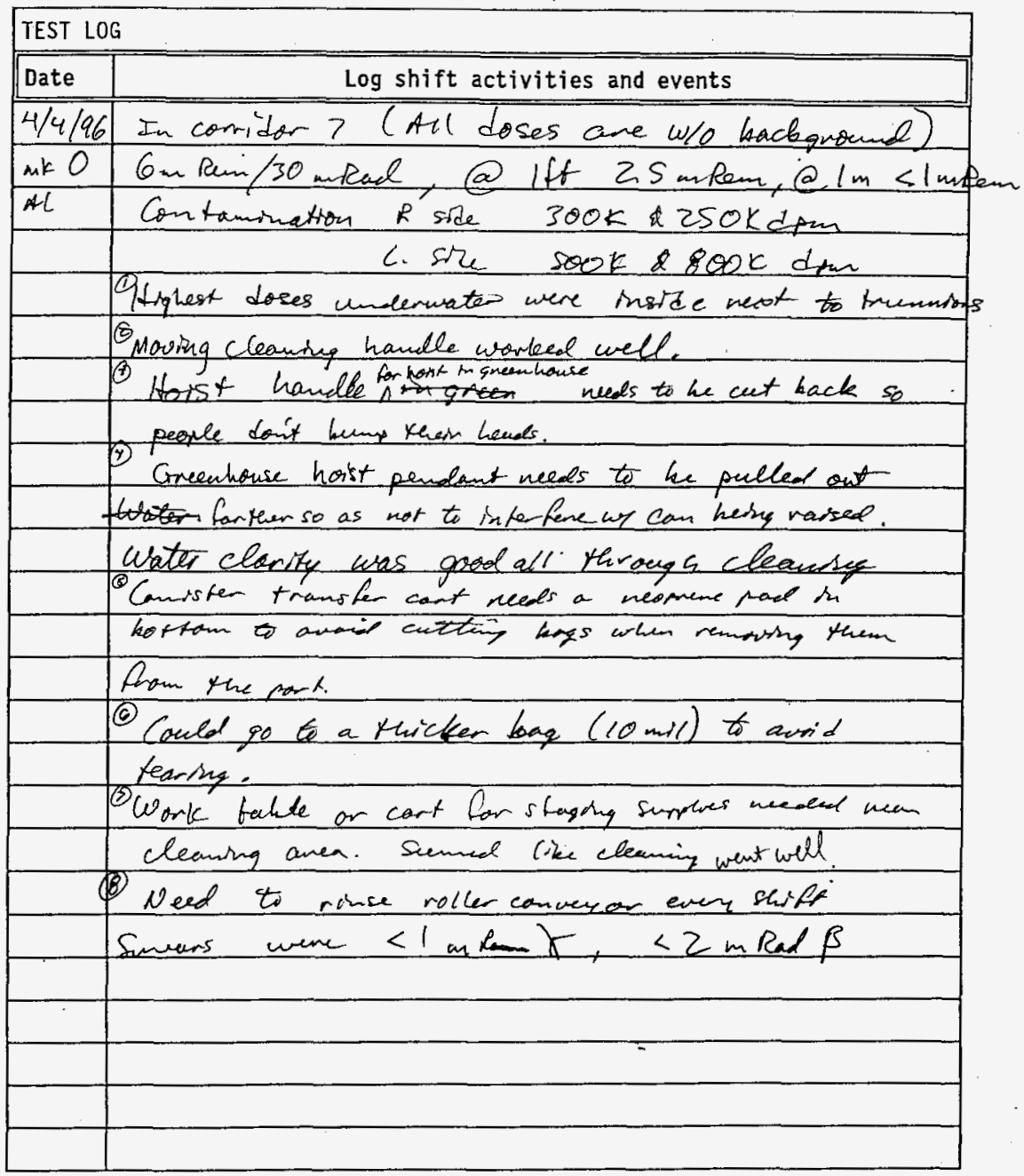

B- 11 
WHC-SD-SNF-0TR-003 revo

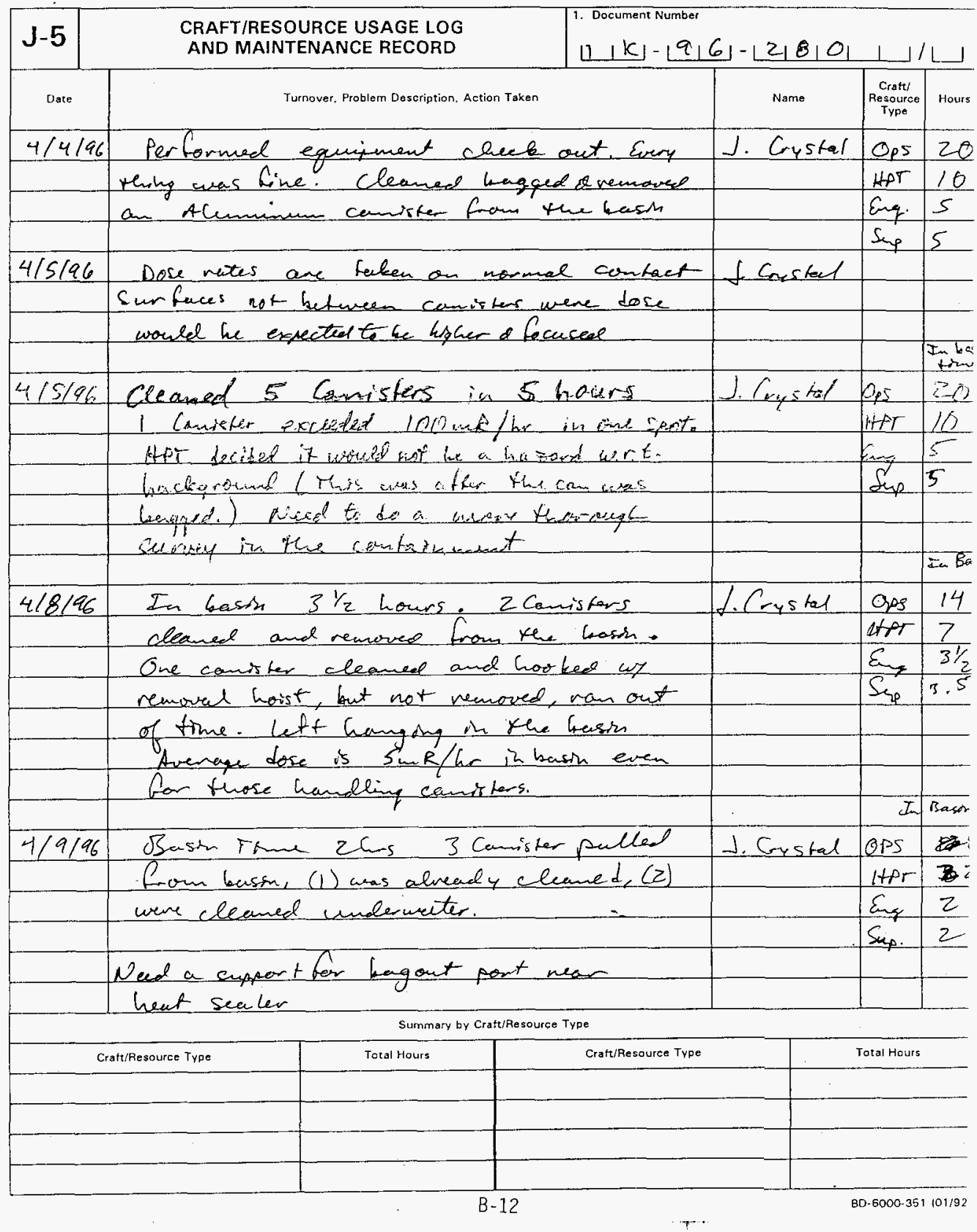




$$
\text { WHC-SD-SNF-0TR-003 revo }
$$

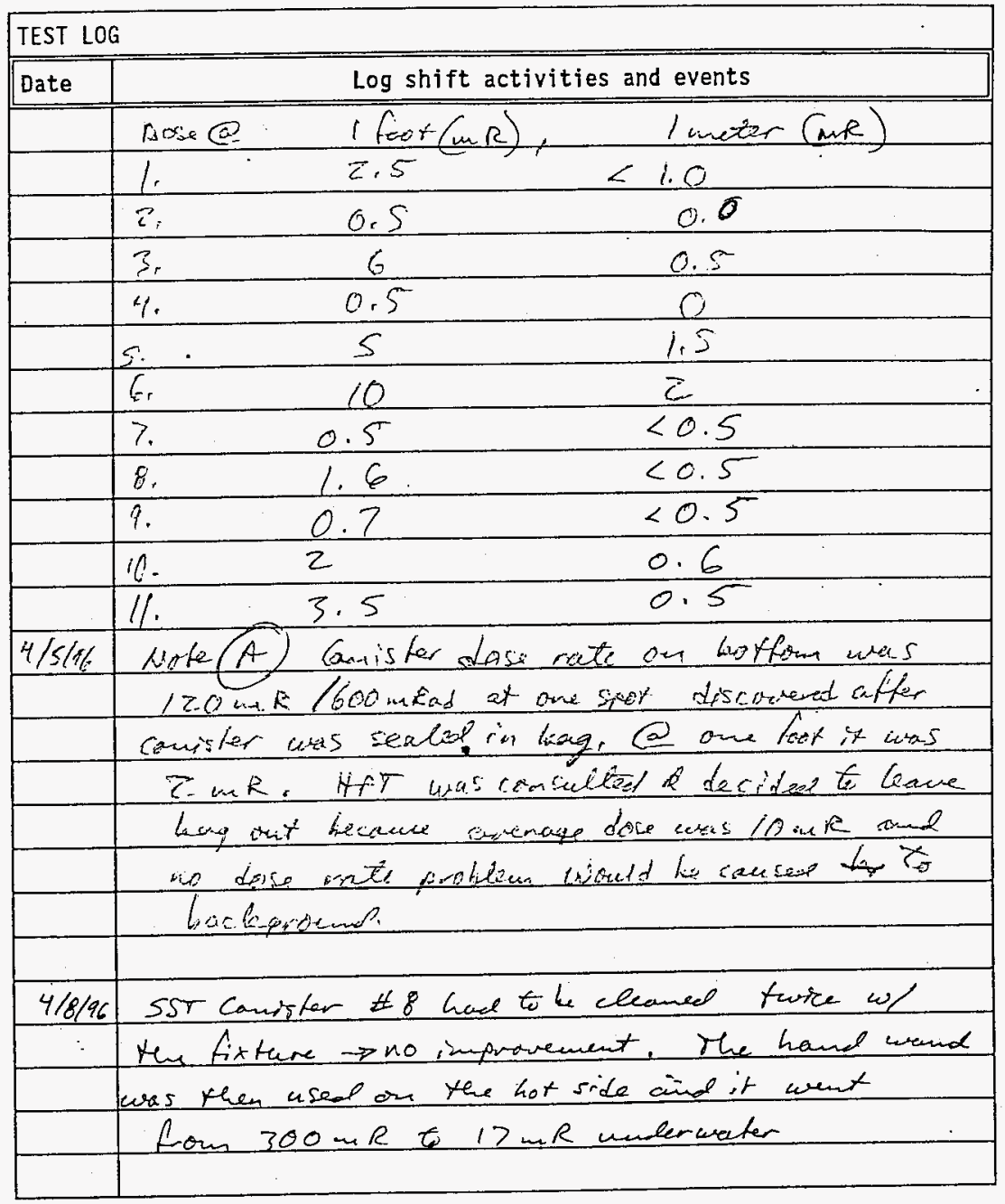

B-13 


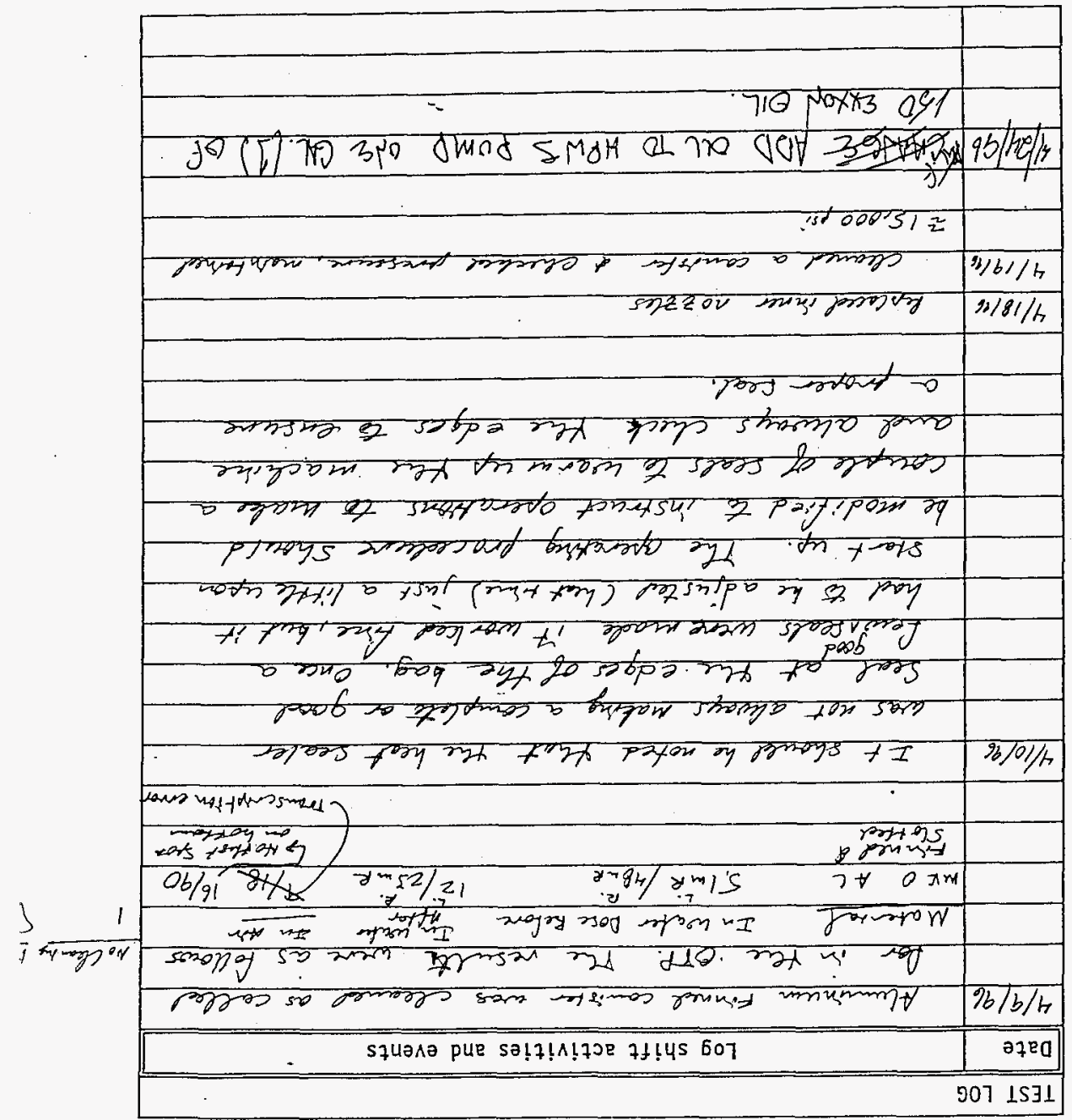


WHC-SD-SNF-OTR-003 revo

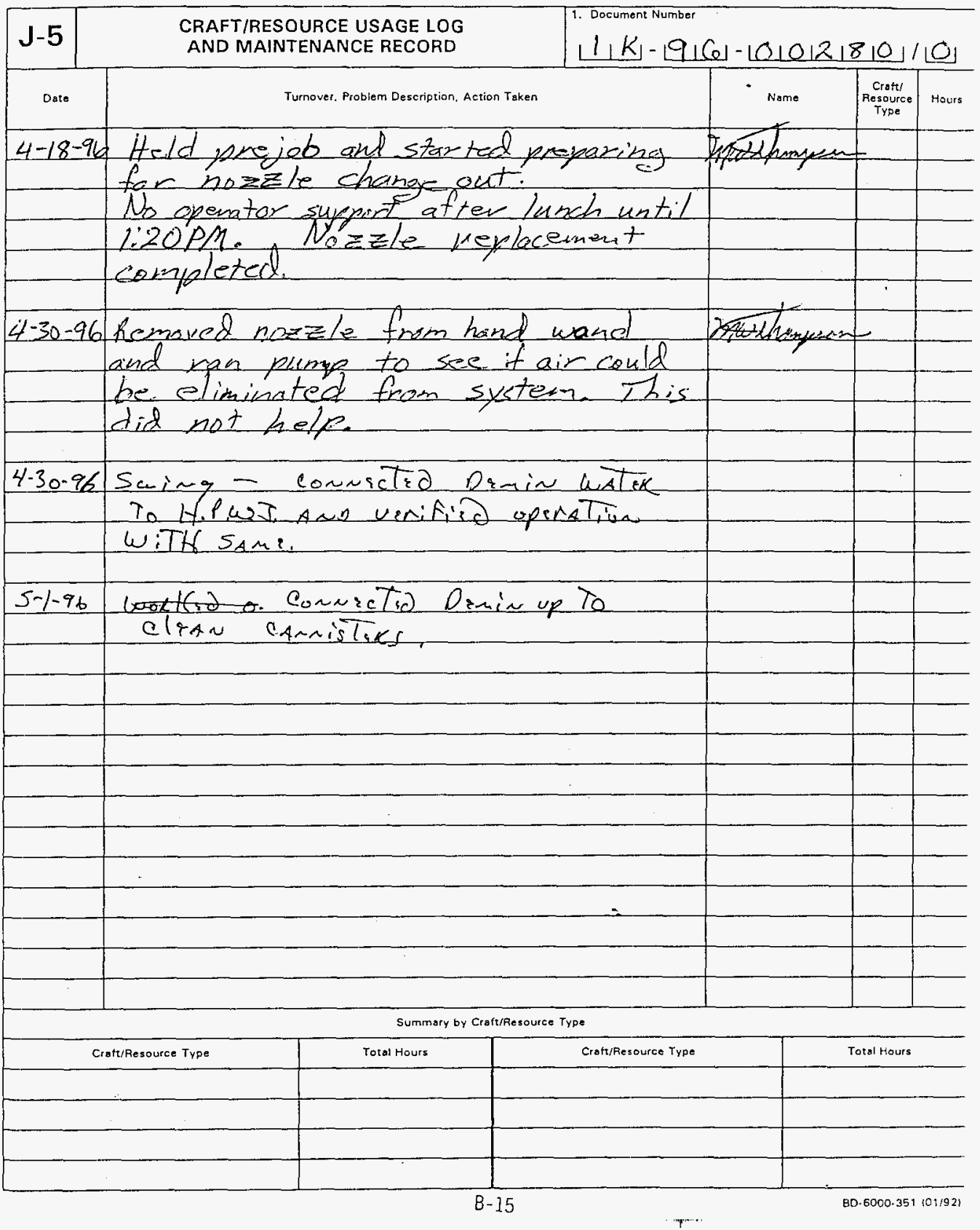


WHC-SD-SNF-OTR-003 rev O

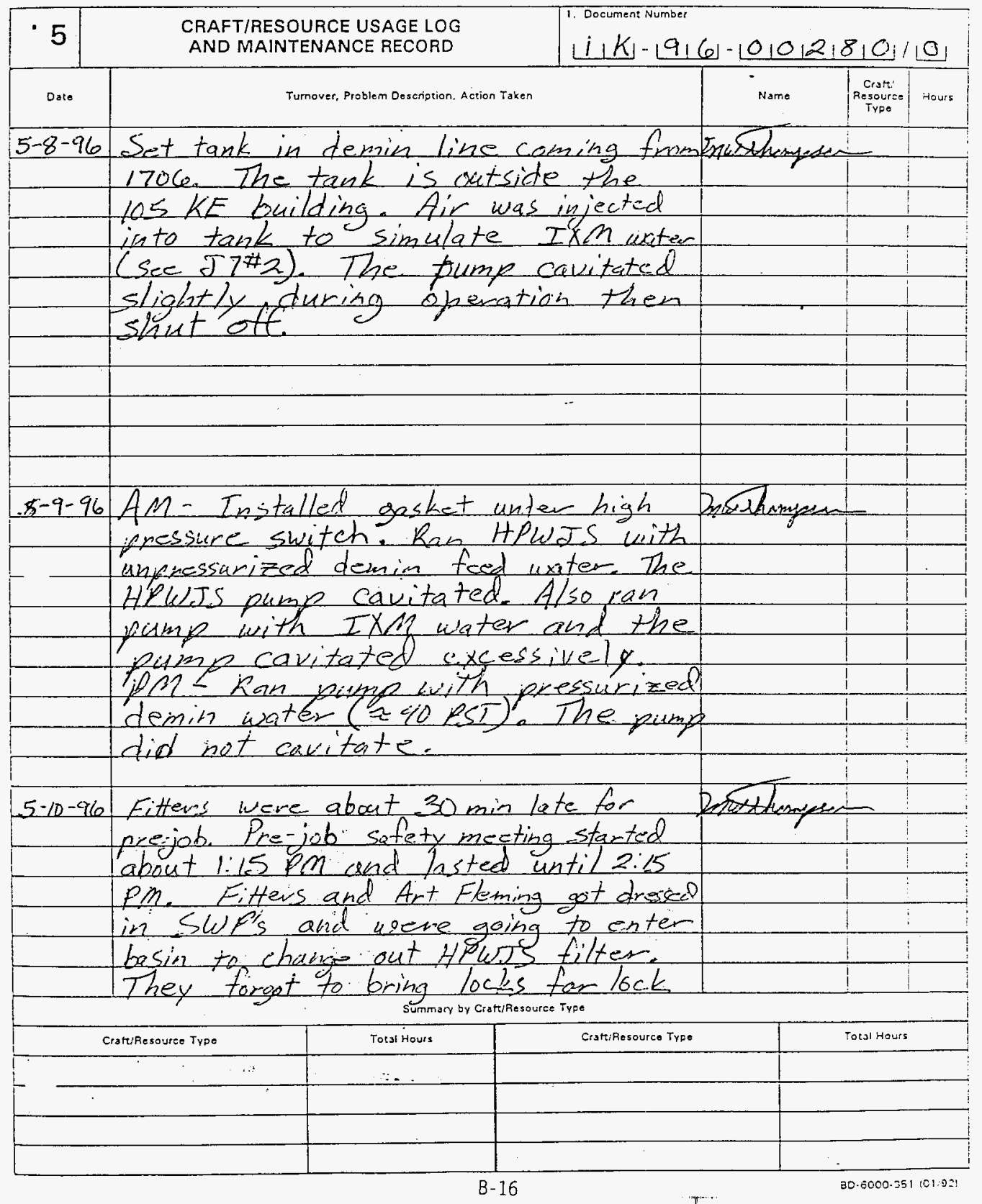


WHC-SD-SNF-OTR-003 revo

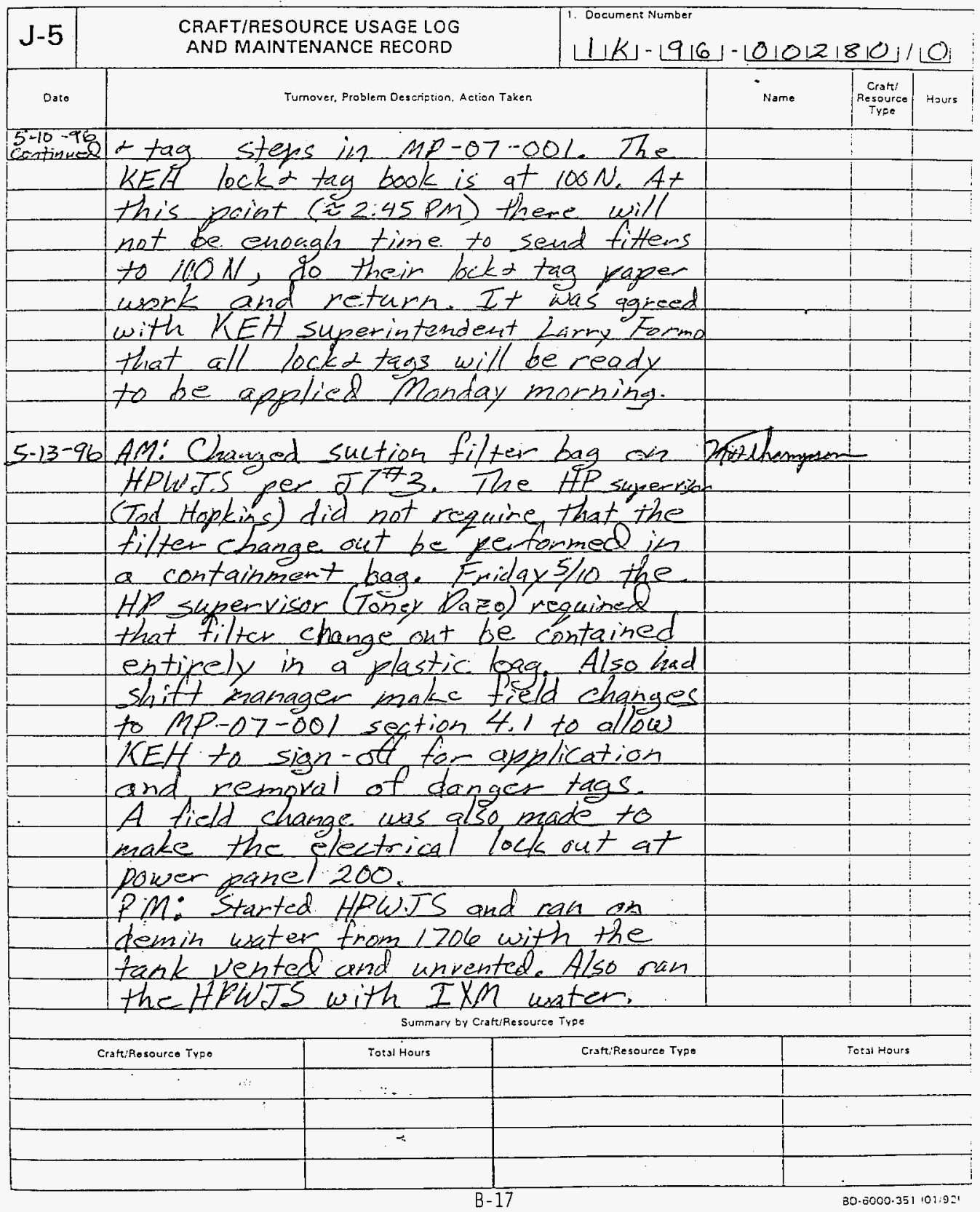


WHC-SD-SNF-OTR-003 revo

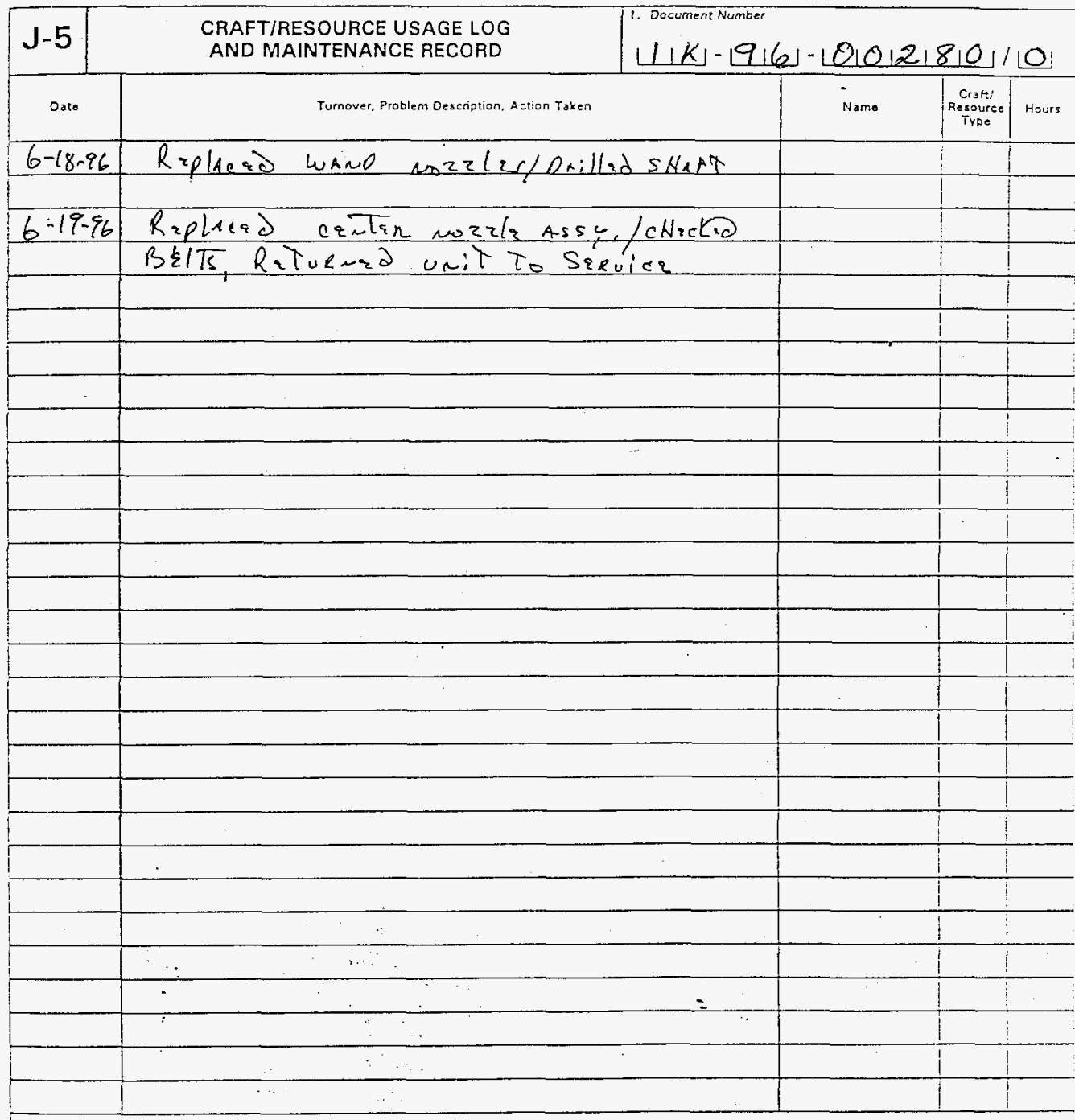

Summary by CrattiResource Type
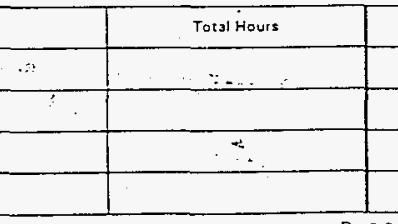

Craft: Fesource Type

Totsl Hours 
WHC-SD-SNF-OTR-003 Rev. 0

Appendix C: OTP Validation

C-1 


\section{Operability Test Procedure K'East Basin Canister Cleaning System}

Jeremy B. Crystal

Westinghouse Hanford Company. Richland. WA 99352

U.S. Department of Energy Contract DE-AC06-87RL10930

EDT/ECN: 140396

Org Code: 2G000

B\&R Code: EW3135040

UC: 510

Charge Code: LD054 ces $3 / 41$ in

Key Words: OTP, Canister, Debris, K East

Abstract: This document provides the guidance necessary to complete the operability testing of the High Pressure Water Jet System installed in KE Basin. Satisfactory test results will enable the equipment to be used in support of the Debris Removal Project.

TRADEMARK DISCLAIMER. Reference herein to any specific commercial product. process, or service by trade name, trademark, manufacturer. or otherwise, does not necessarily constitute or imply its endorsement. recommendation, or favoring by the United States Government or any agency thereof or its contractors or subcontractors.

Printed in the United States of America. To obtain copies of this document, contact: Printed in the United Document Control Services, P.O. Box 1970. Mailstop H6-08. Richland WA 99352, Phone (509) 372-2420: Fax (509) 376-4989.

vans Brader 315196 Relefse Approval

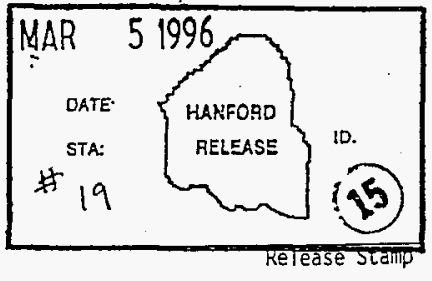

\section{Approved for Public Release}




\section{TABLE OF CONTENTS}

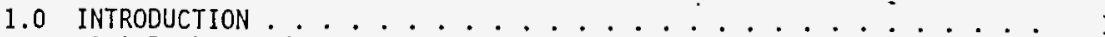

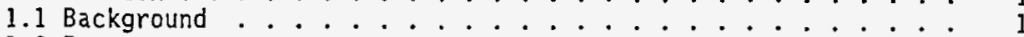

1.2 Purpose . . . . . . . . . . . . . . . . 2

1.3 Scope . . . . . . . . . . . . . . . . 1

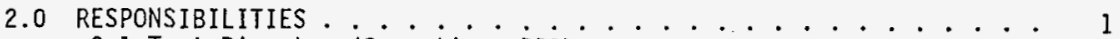

2.1 Test Director (operations PIC) . . . . . . . 1

2.2 Test Engineer . . . . . . . . . . . . . . 2

2.3 Project Technical Representative ............. 2

2.4 Test Performers.................. . . 3

2.5 Qual ity Assurance ................... 3

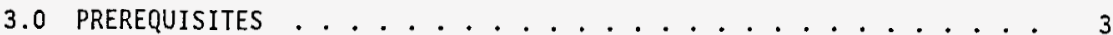

3.1 Completion of Supporting Activities . . . . . . 3

3.2 Operating Procedures ................ 3

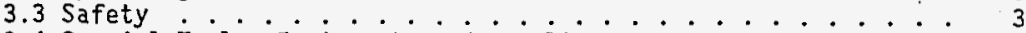

3.4 Special Tools, Equipment, and Supplies .......... 4

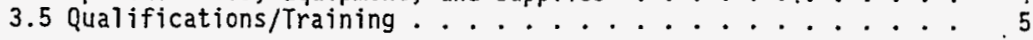

4.0 TEST CONTROL ............................ 5

4.1 Test Discrepancies . . . . . . . . . . . . . 5

4.2 Test Changes ..................... 6

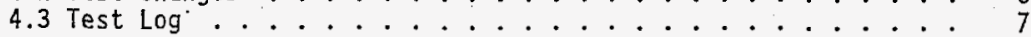

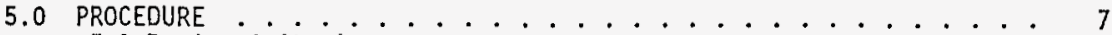

5.1 Design Criteria . . . . . . . . . . . . 7

5.2 System Criteria . . . . . . . . . . . . . 7

5.3 Test Process ................... . . . 8

5.4 Pre-Test Inspection. . . . . . . . . . . . 9

5.5 Test Procedure Steps ................ 9

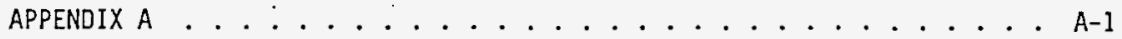

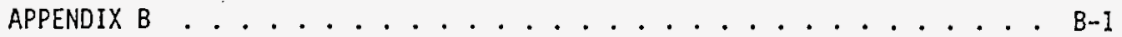

APPENDIX $\mathrm{C} \ldots \ldots \ldots \ldots \ldots \ldots \ldots \ldots \ldots$

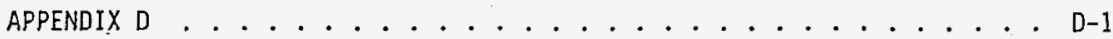

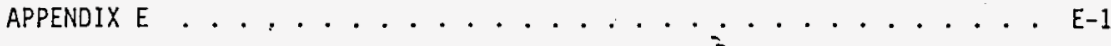


WHC-SD-SNF-OTR-003 rev 0

Butterworth is a registered trademark of Butterworth.

March is registered trademark of March Manufacturing, Inc. 


\author{
WHC-SD-SNF-0TR-003 revo \\ OPERABILITY TEST PROCEDURE \\ FOR THE \\ $K$ EAST BASIN CANISTER CLEANING SYSTEM
}

\title{
1.0 INTRODUCTION
}

\subsection{BACKGROUND}

The operability testing shall demonstrate the capability of the High Pressure Water Jet System (HPWJS) to reduce contamination levels and dose rate on empty fuel canisters prior to removal from the basin and subsequent packaging for disposal.

The HPWJS and the Clean, Remove and Package Empty Canisters Operating Procedures (CC) will be utilized in support of the step-by-step instructions for functionally testing the performance of the specified equipment/system. Facility modifications were completed via the Engineering Change Notice (ECN) process for Electrical Services, IXM Discharge Header, and Grating/Handrail to support and provide a workstation for installation of HPWJS skid and canister cleaning equipment.

The full fuel storage canisters located under the workstation have been moved and relocated to a new area in the basin to provide room for the underwater work table. The basin floor area under the workstation has been vacuumed to remove sludge. The $C C$ equipment has been installed at the workstation located in the center bay of the basin. The HPWJS skid has been installed in the rail/truck bay.

\subsection{PURPOSE}

This operability test provides the instructions to demonstrate a combined canister cleaning system functionality.

\subsection{SCOPE}

The overall scope of the Operability Test Procedure (OTP) is to demonstrate the operability of the Canister Cleaning System installed in the $105 \mathrm{~K}$ East Basin on the Hanford Site. The system was developed and tested per WHC-SC-SNF-TC-004, Development Test Procedure-High"Pressure. Water Jet System.

\subsection{RESPONSIBILITIES}

\subsection{TEST DIRECTOR (OPERATIONS PIC)}

The Test Director is responsible for the following: 
WHC-SD-SNF-OTR-003 revo

- Functioning as the Person In Charge (PIC) for performance as delineated in this procedure.

- Controlling testing activities.

- Assigning responsibilities.

- Monitoring testing for compliance with the test procedures.

- Ensuring Hanford Job Hazards Analysis checklist is complete.

- Conducting prejob briefing/readiness review prior to initiating test and at the beginning of each shift.

The Test Director for this activity is:

\subsection{TEST ENGINEER}

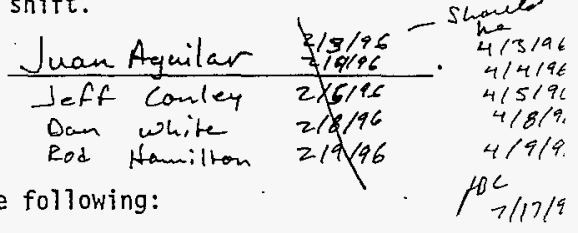

The Test Engineer is responsible for the following:

- Providing project engineering support during testing activities.

- Preparịng test report.

- Providing liaison with the Test Director, Cognizant Engineer, Safety, QA, Environmental, and Project Technical Representative for the sign off of the OTP in Appendix $C$, as required.

- Reviewing test results.

- Ensuring all items requiring operational testing per this procedure are tested.

The Test Engineer for this activity is: Jeremy Crystal

\subsection{PROJECT TECHNICAL REPRESENTATIVE}

The Project Technical Representative(s) (PTR) is responsible for the following:

- Overali technical coordination and dirèction of the special fixtures and equipment including interfacing with equipment vendors.

- Ensuring proper equipment set up, safe operation, and trouble shooting of the system as required.

- Performing a safety walk down of the system prior to the test and record completion of the walk down on the Test Data Sheet, Appendix A. 


\subsection{TEST PERFORMERS}

Test Performers are responsible for performing test activities in accordance with this procedure.

\subsection{QUALITY ASSURANCE}

Witnessing by quality assurance/quality control (QA/QC) personnel may be required for the validated test results and shall be indicated by sign offs on Appendix A, Test Data Sheets.

\subsection{PREREQUISITES}

\subsection{COMPLETION OF SUPPORTING ACTIVITIES} procedure:

The following activities must be complete prior to beginning this

1. Field work completed on 1K-95-845.

2. Field work completed on $1 K-95-846$.

3. Field work completed on 1K-95-847.

4. Field work completed on IK-95-848.

5. Field work completed on $1 K-95-849$.

6. Field work completed on 1K-96-00006/W.

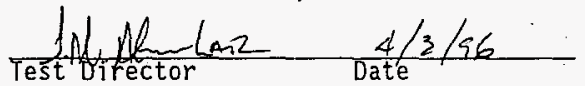

\subsection{OPERATING PROCEDURES}

The following procedures will be utilized for operating equipment during implementation of this OTP, therefore, must be available:

1. HPWJS Operating Procedure, OP 07-101

2. Clean, Remove and Package Empty Canisters Procedure, OP 07-103

3. Tri-Nuc Operating Procedure, OP 07-104

\subsection{SAFETY}

Note: Call 911 in the event of an injury. Inform Emergency Response personnel of cause of injury. To ensure notification for high pressure water injury, operations personnel shall possess a card that is easily accessible and that outlines possible nature of the injury. These cards shall be available at the Shift Manager's office.

3.3.1 Report to PIC any unsafe operations and any possible pinch points. 
3.3.2 At the beginning of each shift, conduct a prejob safety meeting to discuss Radiation Work Permit. (RWP), Job Hazard Analysis (JHA), other permits/limits, and the work anticipated during the shift.

3.3.3 Comply with applicable RWPs and approved Radiation Area Entry Permit.

3.3.4 A JHA form will be required in accordance with WHC-CM-1-10, WKS 6; Pre Job Safety Planning. Existing JHAs may be applicable.

3.3.5 Applicable JHAs and Material Safety Data Sheets (MSDS's) shall be located in the facility test area.

\subsection{SPECIAL TOOLS, EQUIPMENT, AND SUPPLIES}

\subsubsection{Equipment}

- Canister Cleaning Fixture Assembly, Drawing No. H-I-81455

- Greenhouse Assembiy and Rolier Conveyer Table

- Bag Sealer

- Canister Transfer Cart

- R07 underwater/waterproof Radiation Detector Probe and Meter

- Tri Nuclear Vacuum System with Accessories and Hoses

- Underwater Lights (four each)

- Underwater Camera and Monitor

- HEPA Filter/Biower Unit with Hose

The HPWJS contains the following skid mounted components:

- Butterworth T375H, Model 615 ES Pump, 15,000 PSI C 15 G.P.M.

- Electric Motor, Model P44G00 - Reliance Electric, $150 \mathrm{HP}, 460$ Volts, 170 Amps, 3 Phase, $60 \mathrm{~Hz}$.

- Suction Surge Tank. (Ga)vanized, 33 gal with stand, 0-160 psig).

- Stainless Steel Filter Assembly. (10 Micron, 42 g.p.m.).

- Discharge Pressure Control Vessel. (rated 15,000 psi).

- Contactor/Starter - NEMA enclosure, 3R/4 $\frac{1}{2}$ ATL Starter with stand \& conduit, full voltage, reduced voltage, low amperage draw, slow start.

- March Feed Pump, M/N TE-7.5K MD, 2 HP/460V/3PH Motor-2.6 running amps.

\subsubsection{Accessories}

The following accessories may be utilized in varjous combinations to direct and control the water flow from the HPWJS Skid:

- High pressure hose .50 in. 10, 20,000 psi working pressure, 60,000 psi burst pressure, protective outer cover, $9 / 16$ Autoclave Medium Pressure Fittings. 
- Hand Held Wand with $10 \mathrm{ft}$. shielded hose and Slimline Fitting Quick disconnect, 9/16 MP (15,000 psi) Autoclave Medium Pressure Fittings.

- Three Foot Control Valves 15,000 psi. (shut off style) with manifold, piping, fittings mounted on a.work stand.

- Skid Stainless Steel Drip Pan.

- Feed and Drain Hoses.

- Air Manifold and Hoses.

\subsubsection{Supplies}

- Cylinder of Nitrogen (to be stored outside of basin only).

- Flat Plastic Tubing (48 inches $x 50$ feet, three rolls).

- Shipping Containers.

- Indelible marker.

\subsection{QUALIFICATIONS/TRAINING}

3.5.1 The operators shall have completed training for the operation of the HPWJS, Canister Cleaning Fixture, and associated tooling prior to the start of this OTP.

3.5.2 Personnel performing these tests shall be trained and qualified by the HPWJS vendor representative or a vendor certified person for the safe start up, operation, and shutdown of the HPWJS.

3.5.3 Training records will be maintained by the $\mathrm{K}$ Basins Training organization located in M0442.

\subsection{TEST CONTROL}

The OTP is normally performed in the order written. Completion (successful or not) of each major section must be signed by the Test Engineer and a test $\log$ (Appendix $E$ ) entry must be made. At the discretion of the Test Director, some procedure sections may be performed out of order.

Test procedure administrative or editorial changes required during testing may be accommodated as exceptions in the released test report if the changes cannot affect operating facility safety, function or performance and will not compromise test data (WHC-CM-6-1, EP-4.2 Section 2.5).

\subsection{TEST DISCREPANCIES}

Test steps that fail to meet the testing criteria are dispositioned per the instructions listed below, 
NOTE: It should be noted that completing a test discrepancy form is the preferred method of changing the test procedure instructions. In this case, the instructions in Section 4.2 apply.

1. Record the discrepancy in the discrepancy log (Appendix D). A discrepancy that halts the performance of the OTP or otherwise adversely affects the performance schedule will be immediately reported to the Test Engineer.

2. Determine whether to immediately correct the discrepancy, accept the discrepancy as is, or postpone correction to a later date. Record decision for disposition in the space provided on the discrepancy form (Appendix D). A discrepancy correction must meet the original intent of the OTP step unless authorized and documented on the Test Discrepancy Form.

3. Record justification for disposition in the space provided.

4. Obtain necessary signatures to postpone correction or accept condition as is. Corrections performed immediately (within the same shift) do not require approval signatures.

5. Obvious typographical or other clerical errors may be corrected immediately without completing a discrepancy sheet by simply crossing out and initialing by the Test Engineer.

\subsection{TEST CHANGES}

Changes to test instructions may be performed in the field by following these instructions.

1. Test instructions may be changed using the test discrepancy method or by using the ECN method. The test discrepancy method is preferred due to the ease of implementing the change in the field. It should be noted that the field copy of the OTP (including all discrepancy reports) will be released as an Operational Test Report (OTR); therefore, issuance of an ECN against the original OTP would duplicate the effort involved in releasing the OTR.

2. See Appendix $D$ for the test discrepancy form and specific instructions related to the form. :

3. Obtain all required signatures as specified in WHC-CM-6-1, Standard Engineering Practices, Section EP-2.2, "Change Control." Minimum requirements are specified in Appendix D, Test Discrepancy Form.

4. Obvious typographical or other clerical errors may be corrected immediately without completing a discrepancy sheet by simply crossing out and initialing by the Test Engineer. 


\subsection{TEST LOG}

A test $\log$ (Appendix E) will be maintained by the Test Engineer. The test $\log$ will be a running narrative of test activities and status.

\section{0 PROCEDURE}

\subsection{DESIGN CRITERIA}

The following design criteria were considered and included in the design during the development phase:

- ALARA, engineered into the process.

- Minimize handling of items to be cleaned/decontaminated.

- Minimize the moving parts of the special support equipment and water jet fixture heads.

- Ease of operation by the operators.

- Ease of maintenance, replacement of degraded nozzles.

- Minimize cleaning time for each canister.

\subsection{SYSTEM CRITERIA}

The cleaning fixture and/or water pressure may require adjustment if acceptance is not reached during the first test. Tests may be performed as many times as necessary to reach the expected results. The following items shall be demonstrated successfully for acceptance of this OTP:

- Clean the surface of at least ten (10) canisters below Category III, Low Level Waste by reducing the dose rate to less than 100 mrem/hr at contact out of water and less than $20 \mathrm{mrem} / \mathrm{hr}$ at one meter.

- Demonstrate a controlled process for the cleaning/decontamination of canisters underwater with minimal water surface disturbance thereby maintaining air quality within the basin limits.

- Perform the OTP for cleaning/decontamination of canisters, maintaining a minimum of $12,000 \mathrm{psi}$ at the HPWJS skid during the process. $=$

- Perform the step-by-step operating procedures to accomplish OTP demonstrating the effective combinations of fixture nozzles and associated removal equipment.

- No leaks on the HPHJS and hoses during the OTP evaluation.

- Validate that routine (prerequisite) facility systems remain operational during the OTP.

- Hand held wand shall maintain a pressure of 12000 psi (visual at pump) and not leak. 
WHC-SD-SNF-OTR-003 revo

In order to clean finned canisters thoroughily, it may be necessary to use the hand wand in conjunction with the nozzle cleaning cycle.

Successful completion of the OTP and acceptance of the equipment will be documented in Appendix C, Acceptance Sheet.

\subsection{TEST PROCESS}

Underwater and in-air dose rate measurements will be taken by the Health Physics Technicians (HPT) and recorded in Appendix A. Canisters will be retrieved from various locations in the basin and transferred to the work station table canister holder. A pre-cleaning underwater measurement of the dose rate within both cylinders of the canister will be attained and recorded. The cleaning fixture will be manipulated to clean inside and outside of the canister. A post cleaning underwater measurement of the dose rate within both cylinders will be recorded and compared to pre-cieaning measurements. These readings will provide the decontamination factor (DF). Cleaning may be repeated as necessary until the in-water dose rate reading inside the bottom of both cylinders are reading less than $100 \mathrm{mrem} / \mathrm{hr}$ or no decrease in dose rate is realized. If the post cleaning measurement is less than $100 \mathrm{mrem} / \mathrm{hr}$ at contact the canister will be removed from the water into the Drip Dry Greenhouse and surveyed as the canister breaks the water surface. If canister measurement is greater than $100 \mathrm{mrem} / \mathrm{hr}$ at contact, return to water for recleaning. If the hand held wand is utilized, note under comments section on the Test Data Sheet. If repeated cleaning is not successful, transfer to a designated storage area for later processing.

NOTE: Mark II Stainless Steel canister will require standing upright to drain the trunnions.

The following type canisters may be used for the acceptance test: Mark 0, Mark I, and Mark II fuel storage canisters. Five canisters of each material type, stainless steel and aluminum, will be cleaned. At least one of the canisters will be an open bottom style and one will be a finned style for information only.

Once the canister has drip dried (no visible water), it will be removed from the hoist and placed on the roller conveyor. Each canister will be numbered 1 through 10, with an indelible marker, and the right and left cylinders annotated with " $R$ " and "L, " respectively. The HPT will obtain two smear samples from each canister; (1) center of the right cylinder, external surface, and (2) center of the left cylinder, external surface. Additionally the HPT will perform a radiation survey of each canister exterior surface. Dose rate readings of each cylinder center (in the vicinity of the smear sample locations) will be recorded in Appendix B. Smears will be bagged and transferred to the $183 \mathrm{~K}$ East iab for counting analysis. Analytical data obtained from the $183 \mathrm{~K}$ East 1 ab will be summarized under separate report.

The canister is then bagged out through the bag-sealer into a plastic bag and $\mathrm{placed}$ into the transfer cart. The above process is repeated for each of the 10 canisters. 
The transfer cart will hold four bagged canisters. When the cart is full it will be moved to the packaging area for unloading where the canisters will be placed into a shipping container.

\subsection{PRE-TEST INSPECTION}

5.4.1 The PIC, Test Engineer, and PTR shall perform a system walk down prior to start of test to ensure:

- All equipment and tools are properly installed.

- Feed water from the IXM discharge header is connected and valve IXMY-229 is in full OPEN position.

- High pressure hose connections are verified and there are no visible leaks.

- Drain hoses are properly routed and flat plastic is installed at the grating and extends to the water surface.

- Verify that all safety shields and guards are installed.

- Verify that operating procedure steps are implemented and hold points have been signed off.

5.4.2 A satisfactory walk-through shall be documented by the PTR in Appendix A.

\subsection{TEST PROCEDURE STEPS}

These steps may be repeated and/or rearranged at the direction of the Test Engineer/PIC/PTR as necessary to complete the cleaning of at least 10 canisters.

5.5.1 Take a background dose rate in air above water where canister will be removed at base of greenhouse and record in Appendix A.

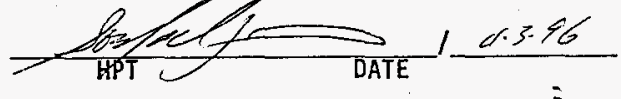

5.5.2 Place underwater radiation detector at the canister holder, measure the background dose rate and record in Appendix A.

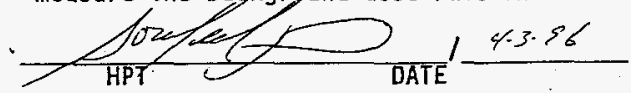

5.5.3 Start the Tri Nuclear Vacuum System per the operating procedure, OP 07-104.

5.5.4 Start the HPWJS per the operating procedure (OP 07-101). Then use the steps in the Clean, Remove and Package Empty Canisters Procedure (OP 07 103) for cleaning the canisters 


$$
\text { WHC-SD-SNF-OTR-003 revO }
$$

5.5.5 Verify that water pressure is set to a minimum of $12,000 \mathrm{psi}$ and sign off in Appendix A.

5.5.6 Position and manipulate the water jet fixture through one fult cleaning cycle for both inside and outside of canister using the CTean, Remove and Package Empty Canisters Procedure (OP 07-103) completing step-by-step. In addition, the following details were added to procedure steps:

5.5.6.1 The pre-cleaning survey performed in Section 4.2 of OP-07-103, shal] be recorded in Appendix A.

Similarly, the post cleaning survey in step 14 of Section 4.3 shall be recorded in Appendix A.

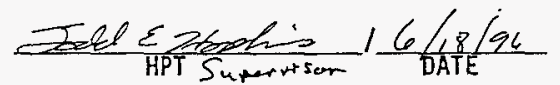

NOTE: Before removing the canister from the water, the dose rate should be less than $100 \mathrm{mrem} / \mathrm{hr}$ at contact. If not, reclean until $<100$ mrem/hr at contact and record number after each cleaning on data sheet. If after several cleanings the dose rate is stilil $>100$ mrem/hr, contact the PIC before transferring canister to the designated storage area. The PIC will record dose rates and maintain an inventory of the rejected canisters.

5.5.6.2 Following Section.4.4, Step 6, of 0P-07-103, perform smear surveys and radiation surveys as described in Section 5.3 of this procedure.

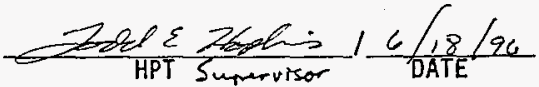

5.5.7 Repeat Sections 4.2 through 4.6 in 0P-07-103 as necessary for each of the 10 canisters.

5.5.8 Shut down HPWJS and Tri-Nuclear pump per operating procedure(s). 